University of Nebraska - Lincoln

DigitalCommons@University of Nebraska - Lincoln

Publications from USDA-ARS / UNL Faculty

U.S. Department of Agriculture: Agricultural

Research Service, Lincoln, Nebraska

$10-26-2020$

\title{
Energy balance in the DSSAT-CSM-CROPGRO model
}

\author{
Santiago V. Cuadra \\ EMBRAPA \\ Bruce A. Kimball \\ USDA Agricultural Research Service \\ Kenneth J. Boote \\ University of Florida \\ Andrew E. Suyker \\ University of Nebraska - Lincoln \\ Nigel Pickering \\ Washington State University
}

Follow this and additional works at: https://digitalcommons.unl.edu/usdaarsfacpub

Part of the Agriculture Commons

Cuadra, Santiago V.; Kimball, Bruce A.; Boote, Kenneth J.; Suyker, Andrew E.; and Pickering, Nigel, "Energy balance in the DSSAT-CSM-CROPGRO model" (2020). Publications from USDA-ARS / UNL Faculty. 2493.

https://digitalcommons.unl.edu/usdaarsfacpub/2493

This Article is brought to you for free and open access by the U.S. Department of Agriculture: Agricultural Research Service, Lincoln, Nebraska at DigitalCommons@University of Nebraska - Lincoln. It has been accepted for inclusion in Publications from USDA-ARS / UNL Faculty by an authorized administrator of DigitalCommons@University of Nebraska - Lincoln. 


\title{
Energy balance in the DSSAT-CSM-CROPGRO model
}

\author{
Santiago V. Cuadra ${ }^{a, *}$, Bruce A. Kimball ${ }^{\mathrm{b}}$, Kenneth J. Boote ${ }^{\mathrm{c}}$, Andrew E. Suyker ${ }^{\mathrm{d}}$, \\ Nigel Pickering ${ }^{\mathrm{e}}$

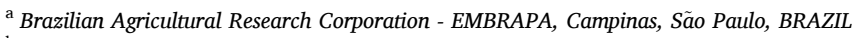 \\ ${ }^{\mathrm{b}}$ U.S. Arid-Land Agricultural Research Center, USDA Agricultural Research Service, Maricopa, Arizona, United States \\ ${ }^{\mathrm{c}}$ Agricultural and Biological Engineering Department, University of Florida, Gainesville, Florida, United States \\ ${ }^{\mathrm{d}}$ School of Natural Resources, University of Nebraska-Lincoln, Lincoln, Nebraska, United States \\ ${ }^{\mathrm{e}}$ Washington Stormwater Center, Washington State University, Pullman, Washington, United States
}

\section{A R T I C L E I N F O}

\section{Keywords:}

Evapotranspiration

Canopy temperature

Leaf temperature

Soil temperature

CROPGRO

DSSAT

\begin{abstract}
A B S T R A C T
One potential way to improve crop growth models is for the models to predict energy balance and evapotranspiration (ET) from first principles, thus serving as a check on "engineered" ET methodology. In this paper, we present new implementations and the results of an energy balance model (EBL) developed by Jagtap and Jones (1989) and then implemented in DSSAT's CROPGRO (CG-EBL) model by Pickering et al. (1995) as a linked energy balance-photosynthesis model that has not been field-tested until now. The energy balance code computes evapotranspiration and other energy balance components, as well as a canopy air temperature, based on three sources (sunlit leaves, shaded leaves, soil surface). Model performance was evaluated with measured biomass and energy fluxes from two sites in Nebraska, namely, the US-Ne2 irrigated maize-soybean rotation field and the US-Ne3 rainfed maize-soybean rotation field, which are part of the Ameriflux eddy covariance network (htt ps://ameriflux.lbl.gov/sites). After implementing new aerodynamic resistances and the stomatal conductance model of the Ball-Berry-Leuning, crop growth, evapotranspiration and soil temperature were simulated well by the EBL model. The EBL improved ET predictions slightly over the often-used FAO56 method [Penman-Monteith (Allen et al., 1998)] for 4 of the 5 years evaluated for both irrigated and rainfed conditions. Further, a significant improvement was achieved using EBL for the simulation of soil temperature at the various depths compared to STEMP, the original subroutine in DSSAT for simulating soil temperature. Compared to the other available DSSAT methods, the EBL explicitly simulates the impacts of crop morphology, physiology and management on the crop's environment and energy and mass exchange, which in turn directly affect the water use and irrigation requirements, phenology, photosynthesis, growth, sterility, and yield of the crop.
\end{abstract}

\section{Introduction}

Crop growth models are widely used tools to assess the likely effects of global change on future agricultural productivity, as well as being a crop management aid for present-day farmers. Although these models are improving rapidly, there are still some important processes that are not incorporated or which are generically parameterized. For example, most models simulate the potential crop transpiration as the product of potential evapotranspiration (ETo) and an empirical crop energyextinction coefficient $\left(\mathrm{k}_{\mathrm{ep}}\right)$ that reduces potential transpiration as a function of crop leaf area index (LAI). One of the limitations of this approach is the decoupling of the transpiration and carbon assimilation by a crop canopy. Another example is that almost all such models "grow" the crops at air temperature, usually measured at a nearby weather station, whereas the actual temperature of crop canopies can deviate several degrees from air temperature (e.g., Jackson et al., 1981, Allen et al., 2003), especially in arid environments. Therefore, one potential way to improve such models is to first have them compute the carbon assimilation and transpiration (largely regulated by the stomatal opening) and the temperature of the crop canopy. Then they can "grow" the crop at that canopy temperature.

Computing the crop canopy temperature, however, generally requires much more coding effort and an accounting of the significant fluxes of energy flowing to and from the crop and soil surfaces. For crops, usually the latent heat of water vapor transfer, i.e. evapotranspiration or water use, is the major energy flux for the dissipation of the

\footnotetext{
* Corresponding author.

E-mail address: santiago.cuadra@embrapa.br (S.V. Cuadra).
} 


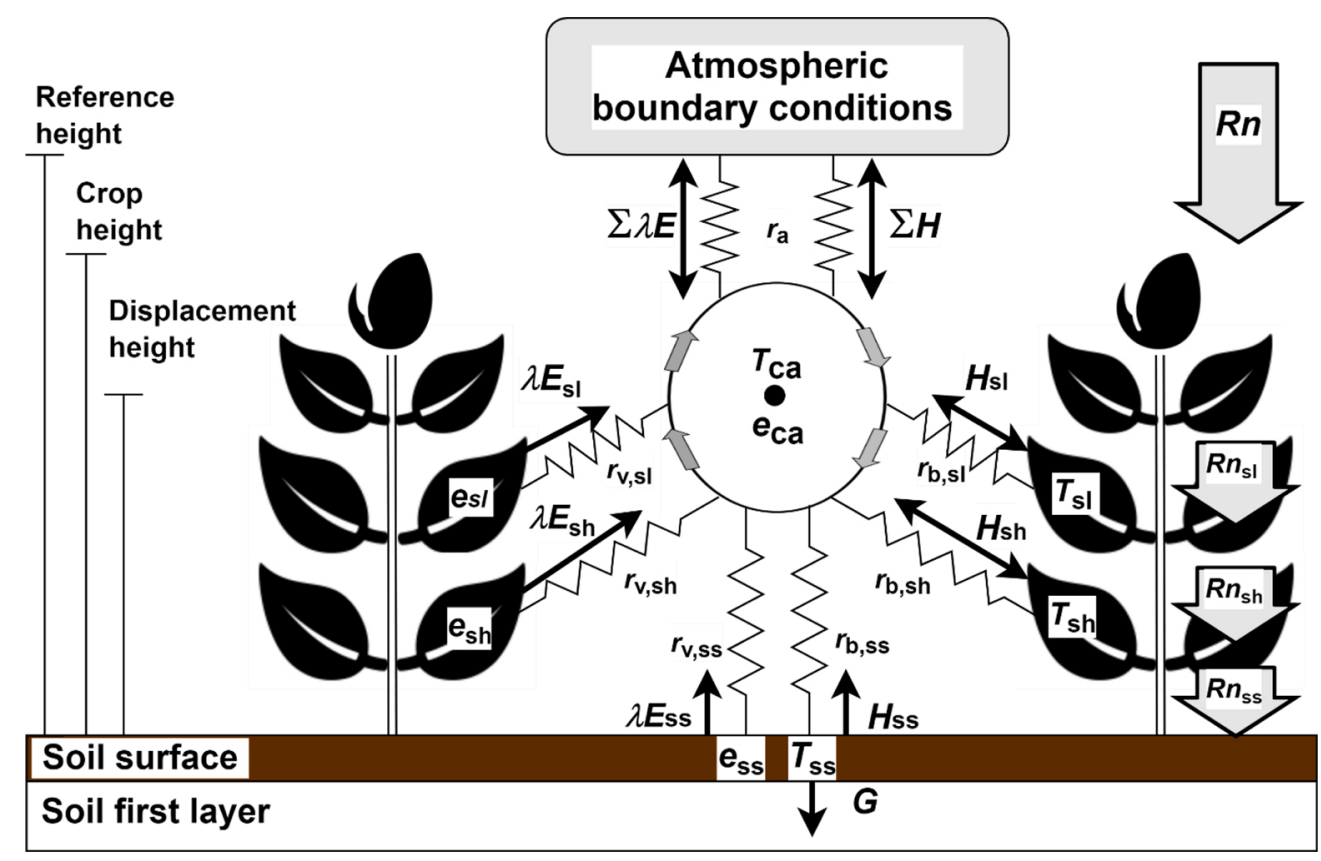

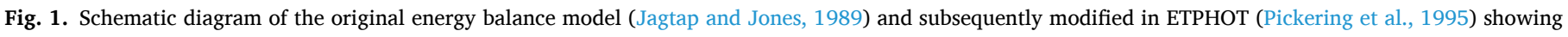
canopy resistances and energy balance components.

net radiation. Therefore, solving for energy balance of a crop canopy provides a method to explicitly compute the impacts of crop morphology and physiology and management on the crop environment and energy and mass exchange. These energy exchanges directly affect the water use and irrigation requirements, phenology, photosynthesis, sterility, growth, and yield.

In addition to the value of simulating a temperature that is closer to the crop's actual temperature, there remains considerable uncertainty in simulation of crop evapotranspiration (e.g., Kimball et al., 2019), possibly because of multiple approaches/equations for simulating potential evapotranspiration and the allocation between actual crop transpiration and soil evaporation. Developing an energy balance approach for simulating crop and soil evaporation and soil temperature is an enhancement over the multiplicity of available ET prediction equations. The energy balance approach in this paper is an alternative that does not rely on any of those formulations, but rather it is based on first principles of soil-crop-atmosphere energy balance and conductivities of the crop and soil to losses and gains of sensible heat and latent heat (water evaporation).

The Decision Support System for Agrotechnology Transfer (DSSAT) family of crop growth models is widely used with thousands of downloads each year (Hoogenboom et al., 2019). One important model within the DSSAT family of Cropping System Models is CSM-CROPGRO (hereafter CROPGRO), which can simulate the growth of many legumes, some non-legumes such as cotton, and some forage crops (Boote et al., 1998; Pequeno et al., 2014, 2018). CROPGRO is a mechanistic model that predicts leaf-to-canopy carbon assimilation on an hourly time step. The CROPGRO model uses daily weather data for input but simulates hourly diurnal weather patterns in an internal loop. Photosynthesis is computed within the hourly loop following a simplification of the Farquhar leaf rubisco-kinetics approach combined with hedge-row canopy geometry to compute light absorption and photosynthesis of sunlit and shaded leaves (Boote and Pickering, 1994; Pickering et al., 1995).
CROPGRO computes photosynthesis and energy fluxes in a subroutine called ETPHOT that was written by Pickering et al. (1995) and placed in the CROPGRO source code more than two decades ago. However, the energy balance capability of that code in CROPGRO is likely to be surprising to many current and potential users because it has been a hidden non-advertised feature in the DSSAT V3.5 release (Boote et al., 1998), which was subsequently inadvertently uncoupled during code "modularization" in the early 2000s. Nevertheless, the code has remained there, but it has only been used for leaf to canopy assimilation, ignoring the coupled energy balance. The energy balance code within ETPHOT computes evapotranspiration (ET) and other energy balance components, as well as a canopy temperature, following a three-source (sunlit leaves, shaded leaves, soil surface) model initially developed by Jagtap and Jones (1989; Fig. 1). While the photosynthesis portion of ETPHOT has been well tested and used for many years, the ET and energy balance portion has not. Therefore, we had three objectives for this study: (1) resurrect the energy balance code within ETPHOT, (2) present some changes that improve the model, and (3) test the ability of the energy balance model (EBL) model to simulate crop ET by comparison with eddy covariance field data on soybean collected as part of the Ameriflux network at Mead, Nebraska, USA.

\section{Materials and methods}

\subsection{CROPGRO/DSSAT model}

The DSSAT platform (Decision Support System for Agrotechnology Transfer, Jones et al., 2003; Hoogenboom et al., 2017, 2019) is one of the most-used crop model platforms (Seidel et al., 2018). It incorporates dynamic crop growth simulation models for over 40 crops. DSSAT simulates crop growth, development, and yield, considering growth in a uniform area under prescribed or simulated management conditions, as well as water, carbon, and nitrogen balance in the soil-plant-atmosphere continuum. The DSSAT has a modular structure in which the different 
components of the various scientific disciplines are structured to allow easy replacement or addition of new modules. The platform has separate soil water, nitrogen, and carbon balance modules and a generic CROPGRO template module, which allows it to simulate different species by defining species-specific parameters (via different input files). For this study, in order to resurrect the dormant energy balance code, we modified the current 4.7 version of DSSAT.

The option to compute evapotranspiration using the energy balance model (EBL) is not currently available in the official v4.7 version of DSSAT, but it can be enabled using a custom parameter. The v4.7 version of the model presented herein (prior to our specific revisions and without the EBL) has been tested using data from hundreds of experiments and diverse crops simulated by the CROPGRO model (Boote et al., 1998; Hoogenboom et al., 2019) to ensure the stability of the code. Our revised code has been submitted to the model development group for approval, and it is anticipated that this EBL option will be available to all CROPGRO users in the next released version of DSSAT.

\subsection{Evapotranspiration and soil temperature methodology used in DSSAT}

Currently, the v4.7 version of DSSAT simulates daily evapotranspiration $\left(\mathrm{ET}, \mathrm{mm} \mathrm{DD}^{-1}\right.$ ) with two user-selected alternative methods, the Priestley-Taylor (PT; 1972) and the FAO-56 [Penman-Monteith (Allen et al., 1998)], as parameterized for CROPGRO by Sau et al. (2004). While the PT method is the default, the FAO- 56 has been recognized as a more accurate method when wind speed and dew point data are
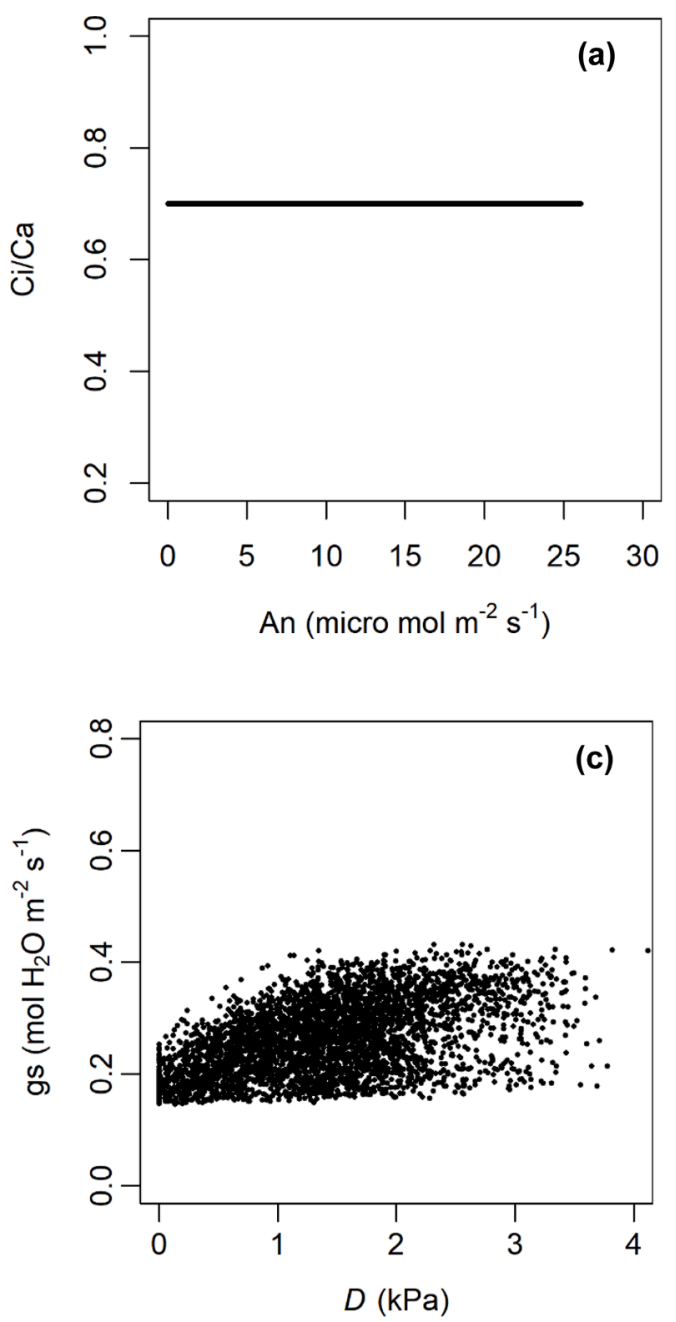

available (Boote et al., 2009; Sau et al., 2004), so we used FAO-56 as the standard for comparison herein. Therefore, CROPGRO with FAO-56 (CG-FAO56) along with the DSSAT STEMP subroutine, that simulates soil temperature (see the description below), is used here for comparisons with the EBL module (described in the next section, Fig. 1) implemented in CROPGRO (CG-EBL). The FAO-56 equation is defined for a reference $12-\mathrm{cm}$-tall grass as:

ETo $=\frac{0.408 * \Delta *\left(R_{\mathrm{n}}-G\right)+\gamma *\left(\frac{900}{T+273}\right) * u_{2} *\left(e_{\mathrm{s}}-e_{\mathrm{a}}\right)}{\Delta+\gamma *\left(1+0.34 * u_{2}\right)}$

where, $\Delta$ is the slope of the vapor pressure-temperature curve $(\mathrm{kPa}$ ${ }^{\circ} \mathrm{C}^{-1}$ ), $R_{\mathrm{n}}$ is the net radiation ( $\mathrm{MJ} \mathrm{m}^{-2} \mathrm{D}^{-1}$ ), $G$ is the soil heat flux ( $\mathrm{MJ} \mathrm{m}{ }^{-}$ $\left.2^{2} \mathrm{D}^{-1}\right), \gamma$ is the psychrometric constant $\left(\mathrm{kPa}^{\circ} \mathrm{C}^{-1}\right)$, $\mathrm{T}$ is the mean daily air temperature $\left({ }^{\circ} \mathrm{C}\right), \mathrm{u}_{2}$ is the mean daily wind speed at $2 \mathrm{~m}$ height $\left(\mathrm{m} \mathrm{s}^{-1}\right)$, $e_{\mathrm{s}}$ is the saturation partial pressure of water vapor at $\mathrm{T}(\mathrm{kPa})$, and $e_{\mathrm{a}}$ is the partial pressure of water vapor in the air $(\mathrm{kPa})$.

Potential crop transpiration is defined as the product of $\mathrm{ET}_{\mathrm{o}}$ and a crop energy-extinction coefficient $\left(\mathrm{k}_{\mathrm{ep}}\right)$ that reduces potential transpiration as a function of crop LAI. The energy not absorbed by the crop (based on $\mathrm{k}_{\mathrm{ep}}$ ), drives potential soil evaporation in the DSSAT models, although actual soil evaporation depends on both potential soil evaporation and soil water content in the Suleiman-Ritchie method (SR; Suleiman and Ritchie, 2003, 2004). These two processes based on $k_{e p}$ effectively replace the typical "dual" crop coefficients that irrigation
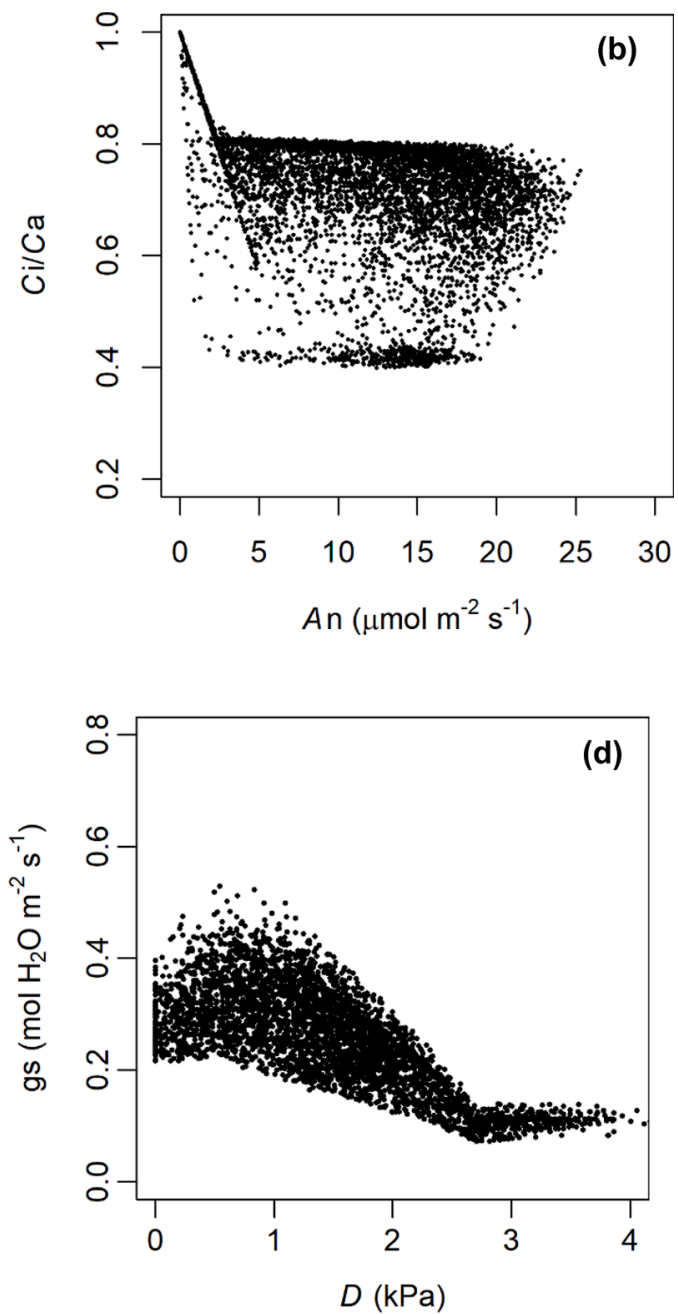

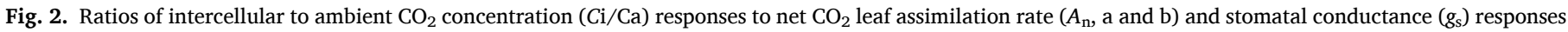

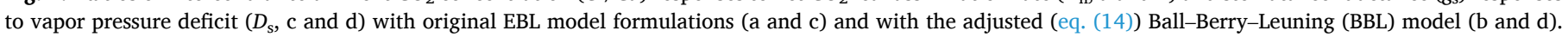


engineers use. There is an additional parameter in CROPGRO for the FAO-56 algorithm called EORATIO, that increases $\mathrm{ET}_{\mathrm{o}}$ above the reference grass $\mathrm{ET}_{\mathrm{o}}$ as a linear function of LAI as LAI increases from 0 to 6 but the effect is minor (see Sau et al. (2004) for implementation of EORATIO).

Daily soil evaporation rate in the default DSSAT code follows the Suleiman-Ritchie (2009) method. As described above, the energy not absorbed by the crop LAI (based on $\mathrm{k}_{\mathrm{ep}}$ ) drives potential soil evaporation, which is the maximum possible daily rate. The SR method computes a soil evaporation rate based on loss (upward flux) of water from the entire soil profile depth based on transfer coefficients per layer that are dependent on soil texture and soil water contents. Actual soil evaporation is the minimum of either potential soil evaporation or SR evaporation.

The current default method for computing soil temperature in DSSAT in a subroutine called STEMP, which is based on a classic annual cosine equation for surface temperature that propagates down from soil layer to soil layer with an attenuation and time lag (e.g., Novak, 2005). The surface temperature equation is based on a given average annual temperature and a given annual amplitude. From day to day, it is modified by the daily maximum temperature, solar radiation, and albedo. Daily minimum temperature does not explicitly appear, which likely led to an overestimation, which will be shown later. The propagation with depth is dependent on the soil heat capacity by layer, which is varied by water content. A 5-day moving average is used to simulate the time lag caused by heat stored in the soil. An empirical equation is used to account for residue and snow on the soil surface and crop biomass above the soil surface.

All DSSAT models have daily potential root water uptake as a function of soil water content and root length density in respective soil layers.

\subsection{The energy balance model}

The Energy Balance (EBL) model was developed by Jagtap and Jones (1989) and then improved and incorporated into the CROPGRO model by Pickering et al. (1995). The following is a summary of the model. The resistance network and energy balance components are shown in Fig. 1. Energy absorbed from incoming net radiation $\left(R_{\mathrm{n}}\right)$ that is dissipated by losses of water vapor or latent heat $(\lambda E)$, sensible heat $(H)$ and soil heat flux $(G)$. Each zone is assumed to exchange energy with a fully-mixed canopy, located at approximately $80 \%$ of the canopy height, where the temperature in the canopy air $\left(T_{\mathrm{ca}}\right)$ and vapor pressure in the canopy $\left(e_{\mathrm{ca}}\right)$ are calculated. The energy is then exchanged from the canopy to the free atmosphere at a reference height, normally more than $1 \mathrm{~m}$ above the canopy top.

The model runs on an internal hourly time step using hourly meteorological values, which are estimated from daily data (Erbs et al., 1982;
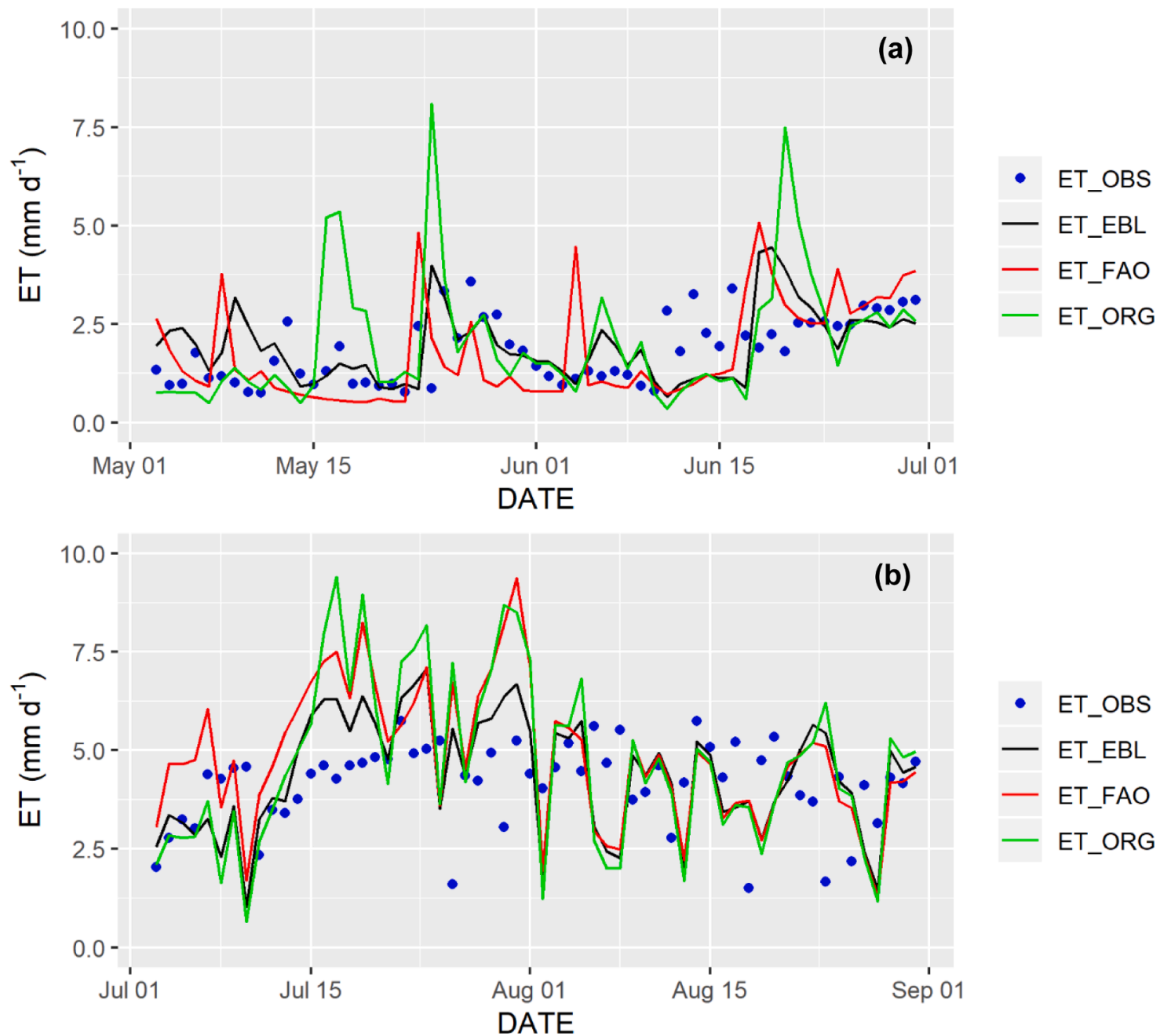

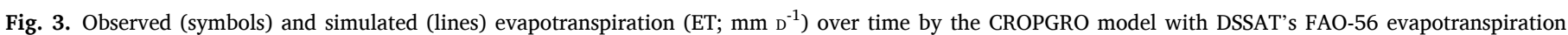

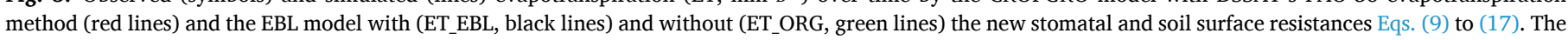

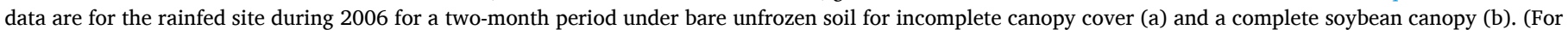
interpretation of the references to colour in this figure legend, the reader is referred to the web version of this article.) 
Parton and Logan, 1981; Spitters et al., 1986b). The light absorption model calculates absorption of direct and diffuse irradiance by sunlit and shaded leaves as a function of canopy height and width dimensions, LAI, leaf angle, row direction, latitude, day-of-year, and time-of-day. The model is solved by considering a balance of energy among three zones or "sources" (Fig. 1): sunlit leaves (sl), shaded leaves (sh) and soil surface (ss). First, net radiation absorbed $\left(R_{\mathrm{ni}} ; \mathrm{W} \mathrm{m}^{-2}\right)$ is calculated for each zone, and then the energy is balanced by the instantaneous sensible $\left(H_{\mathrm{i}}\right)$, latent $\left(\lambda E_{\mathrm{i}}\right)$, and soil $\left(G_{\mathrm{i}}\right)$ heat fluxes.

$R \mathrm{n}_{\mathrm{i}}=\lambda E_{\mathrm{i}}+H_{\mathrm{i}}+G_{\mathrm{i}}$

$\lambda E_{\mathrm{i}}=\frac{\rho C_{\mathrm{p}}}{\gamma} \frac{\left[e_{\mathrm{s}}\left(\mathrm{T}_{\mathrm{i}}\right)-e_{\mathrm{ca}}\right]}{r_{\mathrm{v}, \mathrm{i}}}$

$H_{\mathrm{i}}=\rho C_{\mathrm{p}} \frac{\left(T_{\mathrm{i}}-T_{\mathrm{ca}}\right)}{r_{\mathrm{b}, \mathrm{i}}}$

where $\rho$ is the density of air $\left(\mathrm{kg} \mathrm{m}^{-3}\right), C_{\mathrm{p}}$ is the specific heat of air at constant pressure $\left(\mathrm{J} \mathrm{kg}^{-1} \mathrm{C}^{-1}\right), \gamma$ is the psychometric constant $\left(\mathrm{kPa}^{\circ} \mathrm{C}^{-1}\right)$, $e_{\mathrm{s}}\left(\mathrm{T}_{\mathrm{i}}\right)-e_{\mathrm{ca}}$ are the vapor pressure deficits $(\mathrm{kPa})$ between the three zones and the canopy air, $r_{\mathrm{v}, \mathrm{i}}\left(\mathrm{s} \mathrm{m}^{-1}\right)$ are the three sources resistances to vapor transfer $\left(r_{\mathrm{b}, i}+\right.$ stomatal resistance $), r_{\mathrm{b}, \mathrm{i}}\left(\mathrm{s} \mathrm{m}^{-1}\right)$ are the boundary layer resistances to sensible and latent heat transfers, and $T_{\mathrm{i}}\left({ }^{\circ} \mathrm{C}\right)$ and $T_{\mathrm{ca}}\left({ }^{\circ} \mathrm{C}\right)$ are the temperatures of the three zones and the canopy air (at canopy mid-point), respectively. The heat storage by plants is small compared to the fluxes; therefore, the terms $G_{\mathrm{sl}}$ and $G_{\mathrm{sh}}$ are assumed to be zero. The fluxes from the three zones are balanced with the sensible and latent heat fluxes between the canopy air and the free atmosphere: $\lambda E_{\mathrm{sl}}+\lambda E_{\mathrm{sh}}+\lambda E_{\mathrm{ss}}=\frac{\rho C_{\mathrm{p}}}{\gamma} \frac{\left(e_{\mathrm{ca}}-\mathrm{e}_{\mathrm{a}}\right)}{r_{\mathrm{a}}}$

$H_{\mathrm{sl}}+H_{\mathrm{sh}}+H_{\mathrm{ss}}=\rho C_{\mathrm{p}} \frac{\left(T_{\mathrm{ca}}-T_{\mathrm{a}}\right)}{r_{\mathrm{a}}}$

where $r_{\mathrm{a}}\left(\mathrm{s} \mathrm{m}^{-1}\right)$ is the aerodynamic resistance to heat and vapor transfer. Solution of this model system not only gives the zonal energy fluxes but also yields the zonal temperatures, allowing the crop growth model to be driven by a realistic canopy temperature instead of air temperature, usually measured from the nearest weather station, as in the current DSSAT models. The surface temperatures for sunlit leaves, shaded leaves, and soil are initialized to the current air temperature and the solution procedure uses the top-soil layer temperature from the previous hour. For each hourly time step, the photosynthesis, evapotranspiration, and longwave radiation sub-models need to iterate until a stable canopy air temperature is obtained $( \pm 0.3 \mathrm{C}$ ). If no convergence is obtained within five iterations, then canopy air temperature is set to the average of all iterations. Once stable conditions have been reached, the transpiration rate is compared with the hourly root-water uptake rate. For the EBL, the daily potential root water uptake from DSSAT is translated to hourly with a sine function similar to that used to convert daily solar radiation to hourly. If the transpiration rate is less than the root water uptake rate, there is no further iteration for that time step. If the transpiration rate exceeds the root water uptake rate, there is water stress, which then triggers a modeled reduction in stomatal conductance and transpiration. The evapotranspiration model iterates, progressively reducing the stomatal conductance of both sunlit and shaded leaves until the transpiration and root uptake rates are identical $\left( \pm 0.01 \mathrm{~mm} \mathrm{~h}^{-1}\right)$. The resulting higher leaf temperature is then used to compute leaf

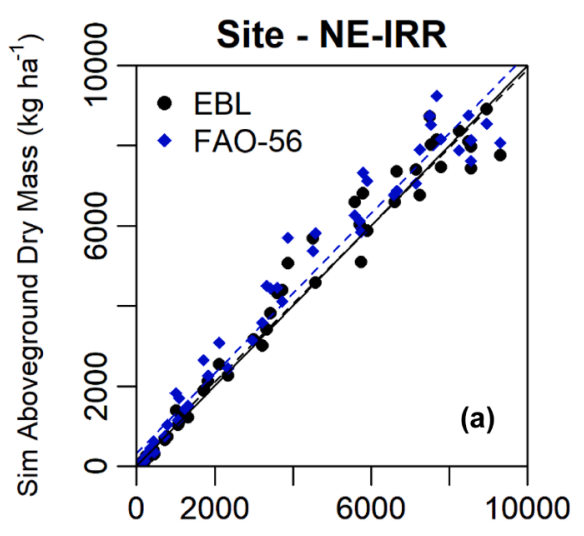

Obs Aboveground Dry Mass (kg ha ${ }^{-1}$ )

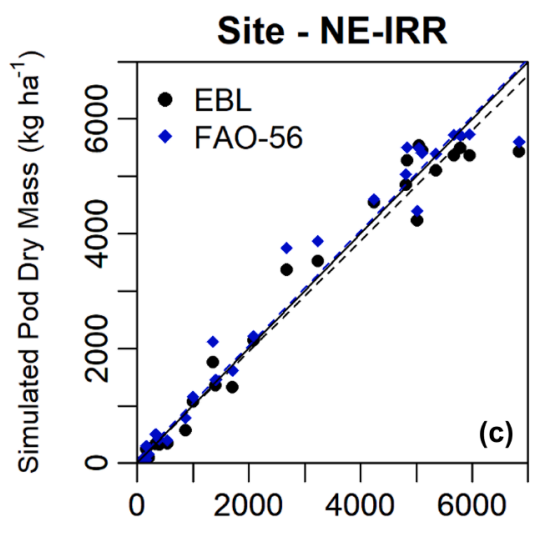

Observed Pod Dry Mass ( $\mathrm{kg} \mathrm{ha}^{-1}$ )

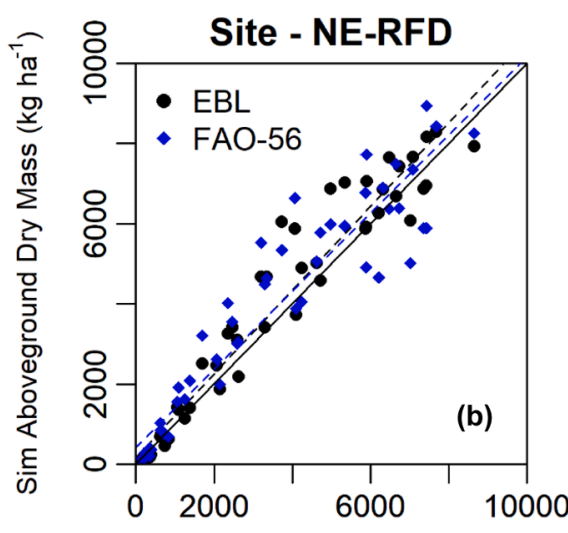

Fig. 4. Observed total aboveground ( $a$ and $b$ ) and pod (c and d) dry biomass $\left(\mathrm{kg} \mathrm{ha}^{-1}\right)$ versus simulated by CROPGRO, with FAO-56 evapotranspiration method (CG-FAO56, blue diamond) and Energy Balance (CGEBL) parametrization (black circle), for irrigated (a and c) and rainfed ( $b$ and d) treatments (all years). The solid black lines are the 1:1 lines. The black and blue dashed lines are the linear regression lines for CG-EBL and CG-FAO56, respectively. (For interpretation of the references to colour in this figure legend, the reader is referred to the web version of this article.)
Obs Aboveground Dry Mass ( $\mathrm{kg} \mathrm{ha}^{-1}$ )

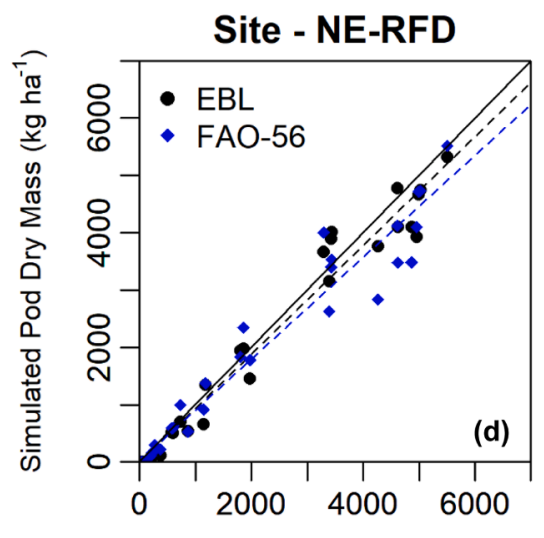

Observed Pod Dry Mass (kg ha ${ }^{-1}$ ) 


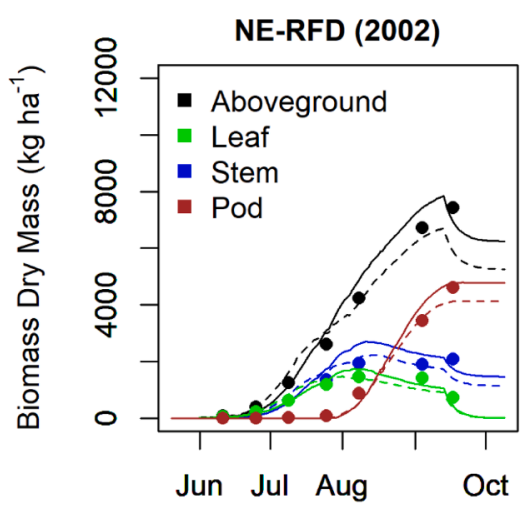

Date

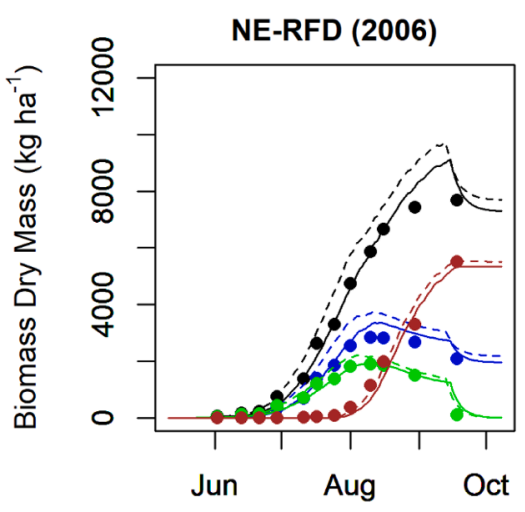

Date

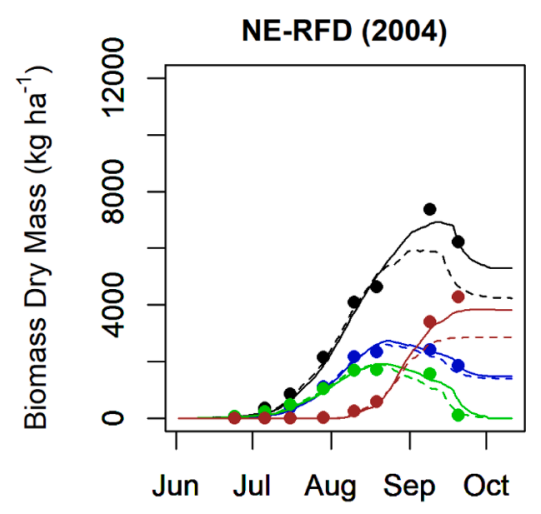

Fig. 5. Observed (symbols) and simulated crop components using CROPGRO with the FAO-56 evapotranspiration method (CG-FAO56, dashed lines) and the EBL model (CG-EBL, solid lines) for the rainfed treatments versus time during the 2002, 2004, 2006, and 2008 growing seasons. The aboveground, leaf, stem, and pod dry biomasses $\left(\mathrm{kg} \mathrm{ha}^{-1}\right)$ are indicated by black, green, blue, and brown colors, respectively. . (For interpretation of the references to colour in this figure legend, the reader is referred to the web version of this article.)

Table 1

Statistical parameters for daily (ET) considering the entire cycle (ET-AVG) and four different periods/conditions: ET days with frozen soil (ET-SF), ET for days with unfrozen soil (ET-SUF), ET for incomplete canopy period (ET-IC, LAI lower than $1.5 \mathrm{~m}^{2} \mathrm{~m}^{-2}$ and ET for complete canopy period (ET-CC, LAI greater than $1.5 \mathrm{~m}^{2} \mathrm{~m}^{-2}$ ). The mean and four statistical measures are from observations and CG-EBL and CG-FAO56 simulations: mean (MEAN), mean absolute error (MAE), root mean square error (RMSE), and D-statistic (D).

\begin{tabular}{|c|c|c|c|c|c|c|c|c|c|c|}
\hline \multirow[b]{2}{*}{ VARIABLE } & \multirow[b]{2}{*}{ TREATMENT } & \multicolumn{3}{|c|}{ ET MEAN $\left(\mathrm{mm} \mathrm{D}^{-1}\right)$} & \multicolumn{2}{|c|}{ MAE $\left(\mathrm{mm} \mathrm{D}^{-1}\right)$} & \multicolumn{2}{|c|}{ RMSE $\left(\mathrm{mm} \mathrm{D}^{-1}\right)$} & \multicolumn{2}{|l|}{ D } \\
\hline & & OBS & EBL & FAO & EBL & FAO & EBL & FAO & EBL & FAO \\
\hline ET-SF & IRRIGATED & 0.98 & 0.93 & 1.25 & 0.59 & 0.56 & 0.75 & 0.77 & 0.58 & 0.72 \\
\hline ET-SUF & IRRIGATED & 2.04 & 2.02 & 2.42 & 0.55 & 0.72 & 0.71 & 0.96 & 0.87 & 0.86 \\
\hline ET-IC & IRRIGATED & 4.11 & 4.12 & 4.43 & 0.59 & 0.63 & 0.73 & 0.82 & 0.91 & 0.90 \\
\hline ET-CC & IRRIGATED & 3.82 & 3.80 & 4.14 & 0.56 & 0.64 & 0.70 & 0.86 & 0.91 & 0.89 \\
\hline ET-SF & RAINFED & 0.92 & 0.95 & 1.25 & 0.64 & 0.57 & 0.84 & 0.81 & 0.52 & 0.69 \\
\hline ET-SUF & RAINFED & 2.01 & 2.25 & 2.32 & 0.84 & 0.70 & 1.03 & 0.94 & 0.75 & 0.86 \\
\hline ET-IC & RAINFED & 3.94 & 3.74 & 3.83 & 0.72 & 0.83 & 0.94 & 1.11 & 0.84 & 0.80 \\
\hline ET-CC & RAINFED & 3.61 & 3.48 & 3.57 & 0.73 & 0.80 & 0.95 & 1.10 & 0.82 & 0.81 \\
\hline ET-AVG & IRRIGATED & 1.88 & 1.84 & 2.16 & 0.51 & 0.56 & 0.67 & 0.78 & 0.96 & 0.95 \\
\hline ET-AVG & RAINFED & 1.78 & 1.81 & 1.98 & 0.64 & 0.60 & 0.86 & 0.86 & 0.92 & 0.92 \\
\hline
\end{tabular}

photosynthesis and the photosynthesis value is reduced by the ratio of water-stressed-to-unstressed leaf conductance.

Net radiation is computed by the net fluxes of shortwave and longwave radiation. Solar radiation absorption is computed using the hedgerow model developed by Boote and Pickering (1994) and also described for an earlier version by Boote and Loomis (1991). The model uses a single-layer approach that approximates a multi-layer model, in which sunlit leaves are effectively above shaded leaves for direct beam absorption while both sunlit and shaded share in diffuse absorption. Three leaf-angle classes are used for sunlit leaves and a single leaf-angle class for shaded leaves. Leaf extinction and reflection coefficients are computed as in Goudriaan (1988) and Spitters et al. (1986a). Hourly meteorological values (described above) drive the hourly radiation computations. Hourly shortwave radiation (infrared irradiance, $\mathrm{W} \mathrm{m}^{-2}$ ) is divided into direct beam and diffuse-sky radiation. Shortwave radiation absorption by sunlit and shaded leaves within the hedgerow (ellipsoidal height and width) is based on a simplification of the ray-tracing approach of Gijzen and Goudriaan (1989) as modified for the hedgerow case (Boote and Loomis, 1991; Boote and Pickering, 1994). Net longwave radiation considers the incoming thermal radiation emission from the sky and outgoing emission from leaves and soil in conjunction with the apparent atmospheric emissivity (Monteith and Unsworth, 1990). Downward longwave radiation uses the apparent atmospheric emissivity to estimate the downward longwave radiation as function of air temperature, relative humidity and cloud fraction. Longwave emission from the sky and land surfaces is computed by the Stefan-Boltzmann Law using the hourly surface temperatures and emissivity. The average land surface emission is calculated as a weighted average from leaves and soil surface using a diffuse radiation view factor. Net longwave radiation is typically outward, i.e. a loss from the 
land surface.

The canopy photosynthesis model is an extension of a hedgerow photosynthesis model (Boote and Loomis, 1991; Boote and Pickering, 1994). The leaves are divided into sunlit and shaded leaf classes (Boote and Jones, 1987) and Gaussian integration is used to sum photosynthesis over the three sunlit leaf-angle classes. The canopy photosynthesis and transpiration components are linked via leaf conductance and temperature. The photosynthesis model first predicts photosynthesis and conductance based on ambient $\mathrm{CO}_{2}$, absorbed radiation, and air temperature. As explained above, the EBL model then uses the leaf conductance to predict canopy transpiration and leaf temperature. Water stress limits the transpiration and leaf conductance, thereby raising leaf temperature and affecting photosynthesis and ET.

Leaf temperature and $\mathrm{CO}_{2}$ effects on quantum efficiency $(\mathrm{QE})$ and the efficiency in translating electron transport into $\mathrm{CO}_{2}$ fixation are modeled using Farquhar and von Caemmerer (1982) Equation 16.60a for limiting RuBP (Ribulose 1,5-bisphosphate). The specificity of the rubisco enzyme for $\mathrm{CO}_{2}$ versus $\mathrm{O}_{2}$ is modeled with an exponential equation that decreases with increasing leaf temperature (Jordan and Ogren, 1984). The rubisco specificity factor (TAU) is used to compute the light compensation point in the absence of dark respiration. There is an additional temperature effect on light- and $\mathrm{CO}_{2}$-saturated photosynthesis (LFMAX) that accounts for the effect of leaf temperature on the rate of electron transport using a lookup table, and also accounts for the effect of
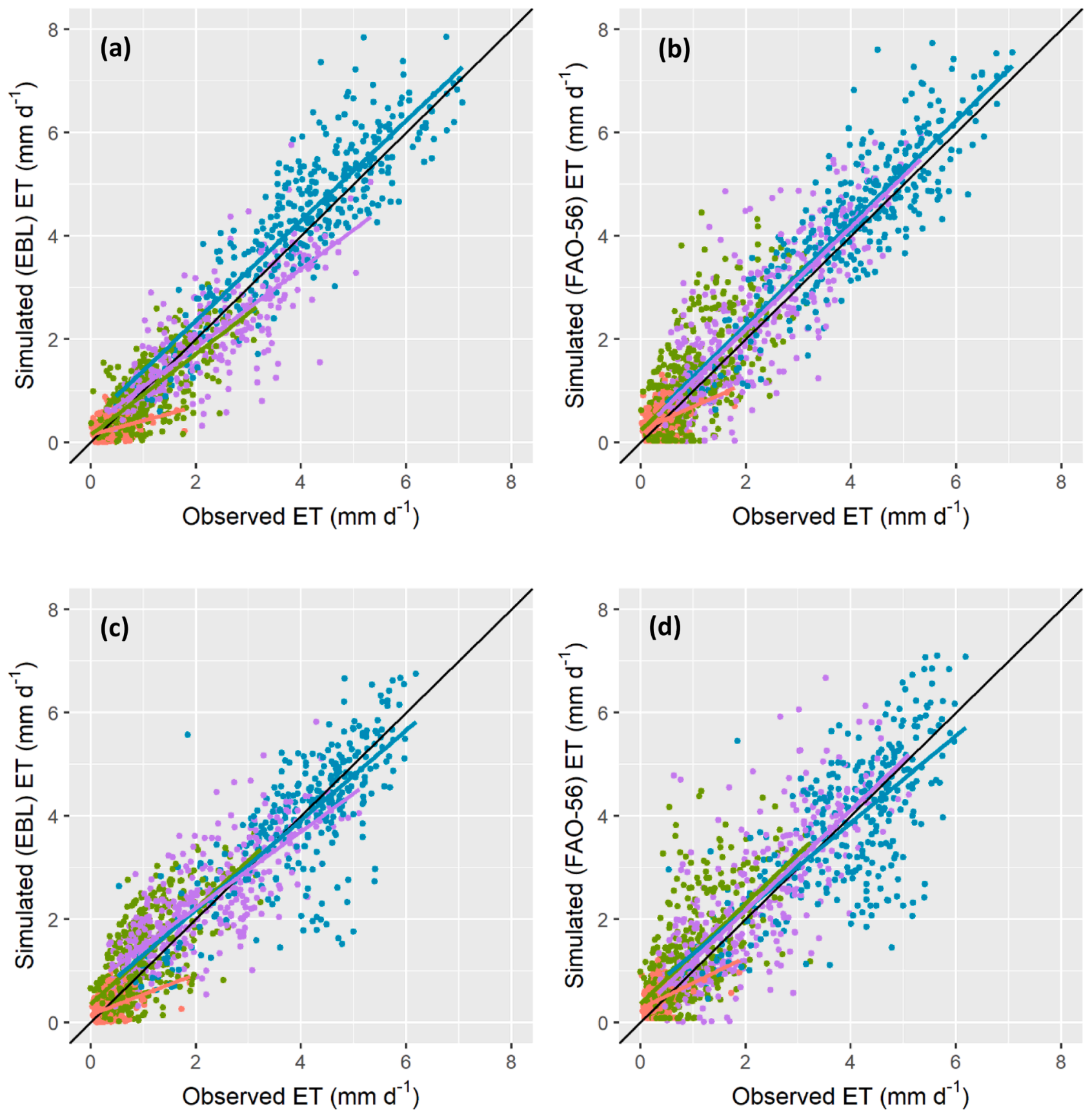

Fig. 6. Observed (eddy covariance, see Section 2.5) evapotranspiration versus simulated evapotranspiration ( $\mathrm{mm}^{-1}$ ) using the EBL model (CG-EBL, a and c) and the FAO-56 evapotranspiration method (CG-FAO56, b and d) for irrigated ( $a$ and b) and rainfed (c and d) treatments (all years). Regressions are presented for four different periods/conditions: Days with Frozen Soil (SF, orange circles), unfrozen Soil (SUF, green triangles), Incomplete Canopy period (IC - LAI lower than $1.5 \mathrm{~m}^{2}$ $\mathrm{m}^{-2}$, purple pluses), and Complete Canopy period (CC - LAI greater than $1.5 \mathrm{~m}^{2} \mathrm{~m}^{-2}$, aqua squares). . (For interpretation of the references to colour in this figure legend, the reader is referred to the web version of this article.) 
denaturization of protein at leaf temperatures above $40{ }^{\circ} \mathrm{C}$. A function called TEMPMX is used to account for the variation of electron transport rate (of photosynthesis) with temperature. The function is species dependent and is generally linear from a cardinal base temperature to the optimum. For soybean the function is linear from 8 to $40{ }^{\circ} \mathrm{C}$ then declines quadratically to zero at $48{ }^{\circ} \mathrm{C}$. This function along with reduction in quantum efficiency caused by the specificity factor of rubisco results in a close match to observed leaf light-and- $\mathrm{CO}_{2}$-saturated photosynthesis measurements on soybean for varying leaf temperatures and $\mathrm{CO}_{2}$ saturation (Harley et al., 1985).

\subsection{New implementations in the EBL model}

We implemented a variable time step to avoid numerical instability in the soil temperature calculation. The model solves the following equation to predict soil temperature:

$G=C \frac{\Delta \mathrm{T}}{\Delta \mathrm{t}}=K \frac{\left(T_{\mathrm{i}}-T_{i-1}\right)}{\Delta \mathrm{z}}$

where, $G$ is soil heat flux $\left(\mathrm{W} \mathrm{m}^{-2}\right)$ between the center of two consecutive soil layers (i and i-1), $C$ is volumetric heat capacity $\left(\mathrm{J} \mathrm{m}^{-3 \circ} \mathrm{C}^{-1}\right), T$ is the temperature of a soil layer $\left({ }^{\circ} \mathrm{C}\right), \Delta \mathrm{t}$ is time step, $\mathrm{K}$ is the thermal conductivity $\left(\mathrm{J} \mathrm{s}^{-1} \mathrm{~m}^{-1}{ }^{\circ} \mathrm{C}^{-1}\right)$, and $\Delta \mathrm{z}$ is the thickness between the center of the soil layers (m). When solving Eq. (7), in order to avoid numerical instability, one has to ensure that $\Delta \mathrm{t} \leq 0.5 \mathrm{C}(\Delta \mathrm{z})^{2} \mathrm{~K}^{-1}$ (https://en. wikipedia.org/wiki/Von_Neumann_stability_analysis). For each hourly model time step this stability term is computed, and whenever $0.5 \mathrm{C}$ $(\Delta \mathrm{z})^{2} \mathrm{~K}^{-1}$ is less than or equal to $3600 \mathrm{~s}$, we decreased the integration time step to solve Eq. (7). For example, if $0.5 \mathrm{C}(\Delta \mathrm{z})^{2} \mathrm{~K}^{-1}$ is equal to 1800 $\mathrm{s}$, we use a half-hour time step instead of one hour to integrate the soil heat flux in the soil.

Additionally, we implemented new formulations for all system resistances. The model considers seven different resistances: the $r_{\mathrm{a}}$, the three $r_{\mathrm{v}, \mathrm{i}}$, and the three $r_{\mathrm{b}, \mathrm{i}}$ resistances.$r_{\mathrm{b}, \mathrm{i}}$ is a three-dimensional vector containing the boundary layer resistances for sensible and latent heat from the sunlit leaves $\left(r_{\mathrm{b}, \mathrm{sl}}\right)$, shaded leaves $\left(r_{\mathrm{b}, \mathrm{sh}}\right)$ and soil surface $\left(r_{\mathrm{b}, \mathrm{ss}}\right)$ to the air at the canopy reference level. $r_{\mathrm{v}, \mathrm{i}}$ is also a three-dimensional vector containing the bulk latent heat resistances of the three zones (sunlit leaves $\left(r_{\mathrm{v}, \mathrm{sl}}\right)$, shaded leaves $\left(r_{\mathrm{v}, \mathrm{sh}}\right)$, and soil surface $\left(r_{\mathrm{v}, \mathrm{ss}}\right)$. For the sunlit leaves, $r_{\mathrm{v}, \mathrm{sl}}$ is the sum of the boundary layer resistance, $r_{\mathrm{b}, \mathrm{sl}}$, plus a stomatal resistance $\left(r_{\mathrm{s}, \mathrm{ll}}\right)$. Similarly, for shaded leaves, $r_{\mathrm{v}, \mathrm{sh}}=r_{\mathrm{b}, \mathrm{sh}}+r_{\mathrm{s}, \mathrm{sh}}$. Finally, for the soil surface, $r_{\mathrm{v}, \mathrm{ss}}$ is the sum of the boundary layer resistance to vapor transfer $\left(r_{\mathrm{b}, \mathrm{ss}}\right)$, from soil to the canopy reference level, plus a soil surface resistance $\left(r_{\mathrm{s}, \mathrm{ss}}\right) . r_{\mathrm{s}, \mathrm{ss}}$ is dependent on the soil water fraction, and it tends to zero as the soil surface water content tends towards saturation.

Pickering et al. (1995) calculated $r_{\mathrm{a}}$ and the $r_{\mathrm{b}, \mathrm{i}}$ resistances using turbulent transfer theory following Choudhury and Monteith (1988).
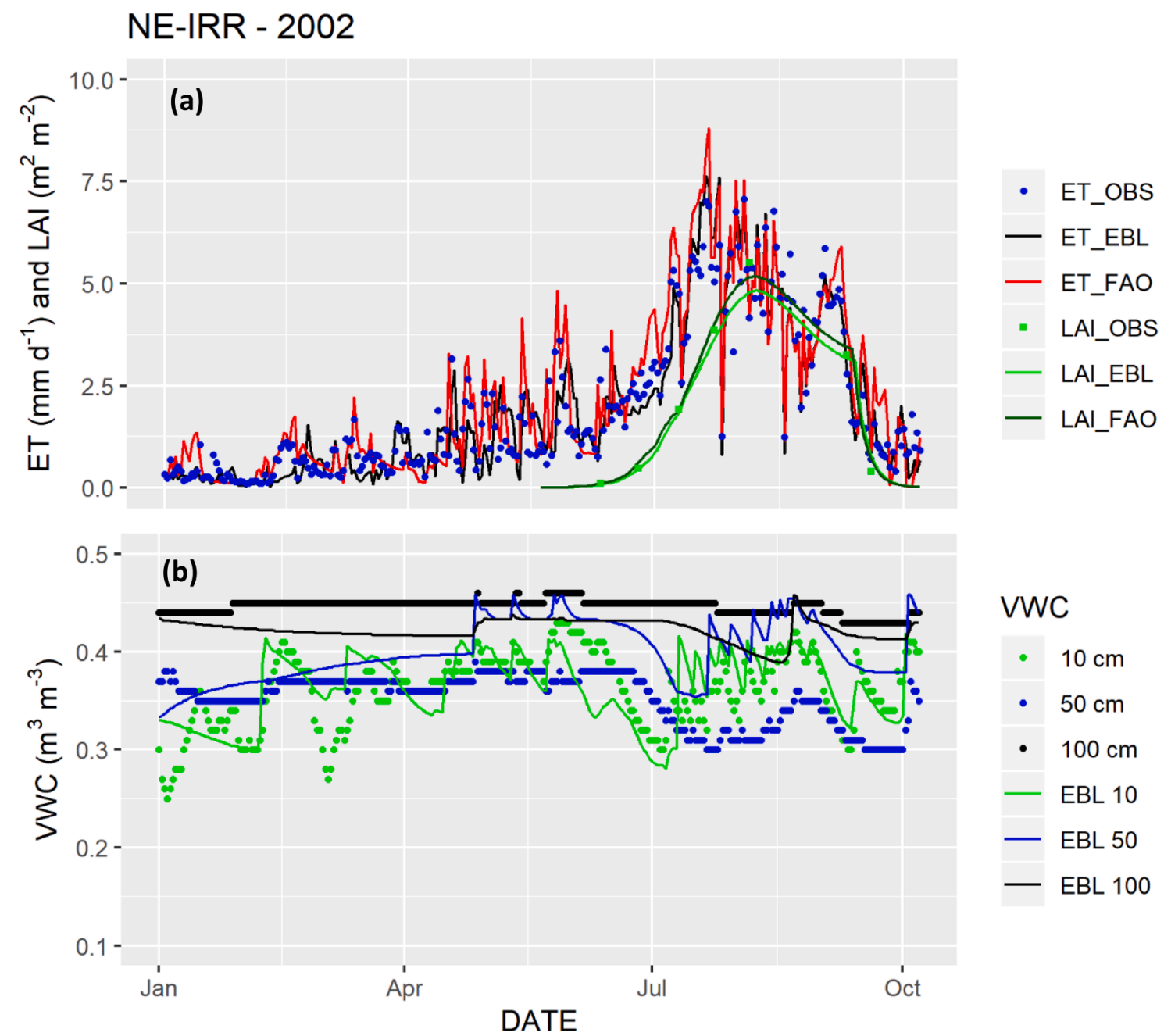

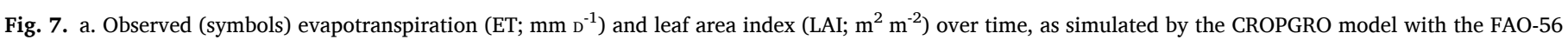

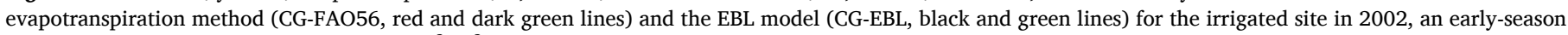

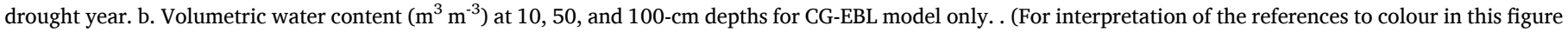
legend, the reader is referred to the web version of this article.) 
However, some model instability problems were encountered during the EBL model integration under calm conditions. As wind speed tended to zero, $r_{\mathrm{a}}$ and $r_{\mathrm{b}, \mathrm{i}}$ tended to infinity, which led to predictions of unrealistically cold or hot canopy temperatures. Therefore, it was necessary to adopt an alternative resistance calculation algorithm for $r_{\mathrm{a}}$ and $r_{\mathrm{b}, \mathrm{i}}$ that considers not only turbulent transport but also natural convection due to thermal gradients. For these calm conditions, we adopted a formula from ASHRAE (1972, p. 40) for natural convection of an infinite plane.

$r_{a}=\rho c_{p}\left(\eta\left|T_{c a}-T_{a}\right|^{1 / 3}\right)^{-1}$

where $\eta$ is an empirical constant, and $\left|T_{\mathrm{ca}}-T_{\mathrm{a}}\right|$ is the absolute temperature difference between $T_{\mathrm{ca}}$ and $T_{\mathrm{a}}$. The same equation is used for $r_{\mathrm{b}}$, ss using $T_{\text {ss }}$ instead of $T_{\text {ca }}$. Kimball et al. (2015) found this equation improved predictions of wheat canopy temperatures under calm, stable conditions and that using $\eta=5.0$ improved fit to their observations, so we have used $\eta=5.0$ herein. For the rare case when both $u$ and $\left|T_{\mathrm{ca}}-T_{\mathrm{a}}\right|$ go to zero, following Kimball et al. (2015), we used $r_{\mathrm{a}}=\rho c_{\mathrm{p}} / 2.32$, which is equivalent to $\left|T_{\mathrm{ca}}-T_{\mathrm{a}}\right|=0.1{ }^{\circ} \mathrm{C}$ with $\eta=5.0$.

For EBL, the daily water available for evaporation from soil (E) is defined as the total water content within the first soil layer or from the first $n$ layers, as defined by the user. For example, if the user sets the first two layers to a depth of $5 \mathrm{~cm}$ each and $n$ as 2 the daily water available for $\mathrm{E}$ is the sum of the water content in these two layers. One potential problem is that if the daily total water available uses a deep layer, $20 \mathrm{~cm}$ for example, $E$ is often overestimated (with peaks twice as high as observed on days with high evaporative demand). As result, in the days after rainfall or irrigation events, the EBL model as initially formulated tended to overpredict $\mathrm{E}$. This was caused by the immediate availability of a large amount of water and an underestimation of the surface resistance to the water flux from the soil surface to the air $\left(r_{\mathrm{v}, \mathrm{ss}}\right)$; because $r_{\mathrm{s}, \mathrm{ss}}$ is based on the soil water fraction in the $n$ layers, $r_{\mathrm{s}, \mathrm{ss}}$ is an exponential function of soil volumetric water fraction. To solve this problem, we implemented a shorter time step (nominally one hour) for the total water available for $E$, which is the integral of the water content in the first $n$ soil layers defined by the user. At the first hour of the day we split the water content available for $\mathrm{E}$ into two amounts (layers):

$S W U=S W E \times\left(\frac{S W U D}{S W E D}\right)$

$S W E=S W E-S W U$

where, SWU (mm) is the amount of the SWE (daily total soil water that is available for E) that can be depleted from E in a time step, SWUD is the depth that provides water to SWU and SWED is the total soil layer depth summed over the first $n$ layers (as defined by the user) that provides water to SWE. SWU directly affects $r_{\mathrm{s}, \mathrm{ss}}$ and provides water to E. We assume that at night there is a homogenization of the fractions of the volumetric water content between the two soil water amounts (layers). During each hour of the day, E subtracts water from SWU, and the water fraction in the SWU is lower than in the SWE. As the soil water fraction exponentially impacts the $r_{\mathrm{s}, \mathrm{ss}}, r_{\mathrm{s}, \mathrm{ss}}$ increases during daytime and reduces the rate of E. SWU is updated every time step based on the soil water

\section{NE-RFD - 2002}
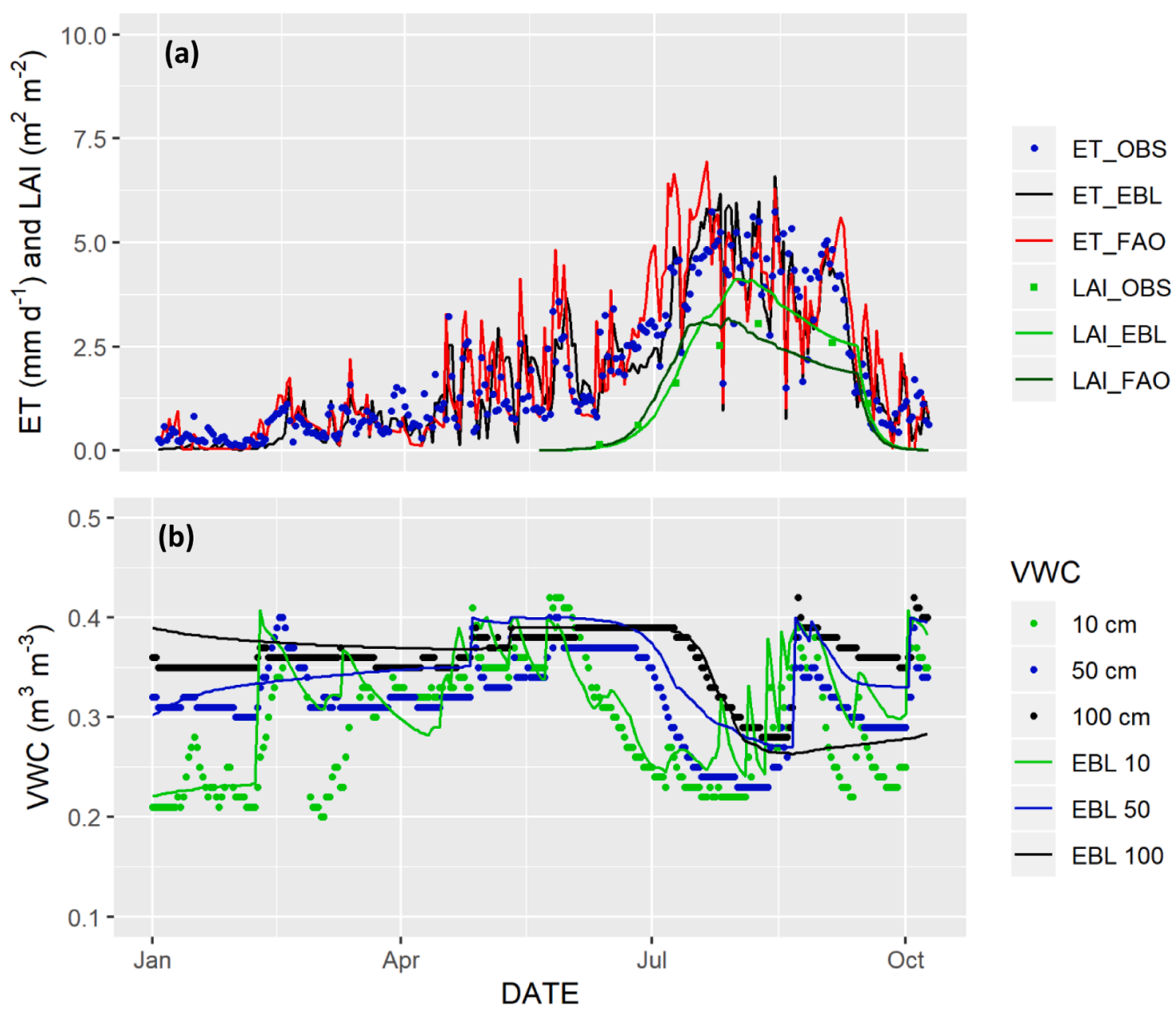

Fig. 8. The same as Fig. 7, but for rainfed treatment. 
upward flux, from SWE, and the loss from E:

$S W U_{t}=S W U_{t-1}+t w \times\left\{\left[\left(\frac{S W E}{S W E D}\right)-\left(\frac{S W U}{S W U D}\right)\right] \times S W U D\right\}-E$

$S W E_{t}=S W E_{t-1}-t w \times\left\{\left[\left(\frac{S W E}{S W E D}\right)-\left(\frac{S W U}{S W U D}\right)\right] \times S W U D\right\}$

where $\mathrm{SWU}_{\mathrm{t}}$ and $\mathrm{SWU}_{\mathrm{t}-1}$ are the amounts of water at the present and previous time steps, respectively. Thus, terms in square brackets are the differences between the volumetric water fractions of the layers and the term $t w$ is the number of time steps to achieve an equilibrium between the two layers. For example, if we set $t w$ as 1 , every time step SWU and SWE reach equilibrium; i.e., both layers reach the same volumetric water fraction.

Stomatal resistances $\left(r_{\mathrm{s}, \mathrm{sl}}\right.$ and $\left.r_{\mathrm{s}, \mathrm{sh}}\right)$ in Pickering (2013) were originally solved simply from the net leaf photosynthesis, and it was assumed that the internal $\mathrm{CO}_{2}$ concentration was a constant fraction of atmospheric concentration $\left(C_{\mathrm{i}} / C_{\mathrm{a}}\right.$ ratio was 0.7$)$. Both resistances are now computed using an adaptation Eqs. (14)-(15) of Ball-Berry-Leuning (BBL)'s model (Leuning, 1995; Miner et al., 2017). Eq. (13) presents the original BBL model:

$g_{\mathrm{s}}=g_{0}+\frac{m \times \mathrm{A}_{\mathrm{n}}}{\left(C_{\mathrm{s}}-\Gamma\right) \times\left(1+\frac{D_{\mathrm{s}}}{D_{0}}\right)}$ where $g_{0}$ is the minimum water vapor stomatal conductance $\left(m o l \mathrm{H}_{2} \mathrm{O}\right.$ $\left.\mathrm{m}^{-2} \mathrm{~s}^{-1}\right), m$ is the slope of the conductance-photosynthesis relationship, $A_{\mathrm{n}}$ is the net $\mathrm{CO}_{2}$ leaf assimilation rate $\left(\mu \mathrm{mol} \mathrm{CO} \mathrm{Cm}^{-2} \mathrm{~s}^{-1}\right), C_{\mathrm{s}}$ is the $\mathrm{CO}_{2}$ concentration at the leaf surface ( $\left.\mu \mathrm{mol} \mathrm{mol}{ }^{-1}\right), \Gamma$ is the $\mathrm{CO}_{2}$ compensation point $\left(\mu \mathrm{mol} \mathrm{mol}^{-1}\right), D_{\mathrm{s}}$ is the leaf-to-air vapor pressure difference $(\mathrm{kPa})$, and $\mathrm{D}_{0}$ is a fitted parameter $(\mathrm{kPa})$. In this equation it is difficult to separate and adjust the effects of $A_{\mathrm{n}}$ and $D_{\mathrm{s}}$ through the parameters $m$ and $D_{0}$, making interpretation and calibration difficult (Miner et al., 2017). We modified the original BBL model by considering that the $D_{\mathrm{s}}$ can start to influence the stomatal opening only beyond a certain value, i.e., under conditions of low $D_{\mathrm{s}}$ it has no influence on the stomatal opening (e.g., Gilbert et al., 2011). By contrast, the original BBL equation (eq. (13)) has $D_{s}$ effect starting at zero $D_{s}$. To separate the effects of $A_{\mathrm{n}}$ and $D_{\mathrm{s}}$ and have a better and clearer control of the effect of $D_{\mathrm{S}}$ on conductance, we changed the equation for computing the effect of $D_{\mathrm{S}}$ on $g_{s}$ as follows:

$g_{\mathrm{s}}=g_{0}+\frac{m \times A_{\mathrm{n}} \times D_{\mathrm{ef}}}{\left(C_{\mathrm{s}}-\Gamma\right)}$

$D_{\text {ef }}=1+D_{\text {sslp }} \times\left(D_{\mathrm{s}}-D_{\text {sst }}\right)$

where, $D_{\text {ef }}(0.0$ to 1.0$)$ is the $D_{\mathrm{s}}$ reduction effect on $g_{\mathrm{s}}, D_{\mathrm{sslp}}$ is the slope of the $D_{\mathrm{s}} \times g_{\mathrm{s}}$ relationship, and $D_{\mathrm{sst}}$ is the reference value where $D_{\mathrm{s}}$ starts to have an effect on $g_{s}$; i.e., when $D_{s}$ is below this reference value $D_{\text {ef }}$ is 0.0 , and $g_{\mathrm{s}}$ does not respond to $D_{\mathrm{s}}$. Additionally, we included two new
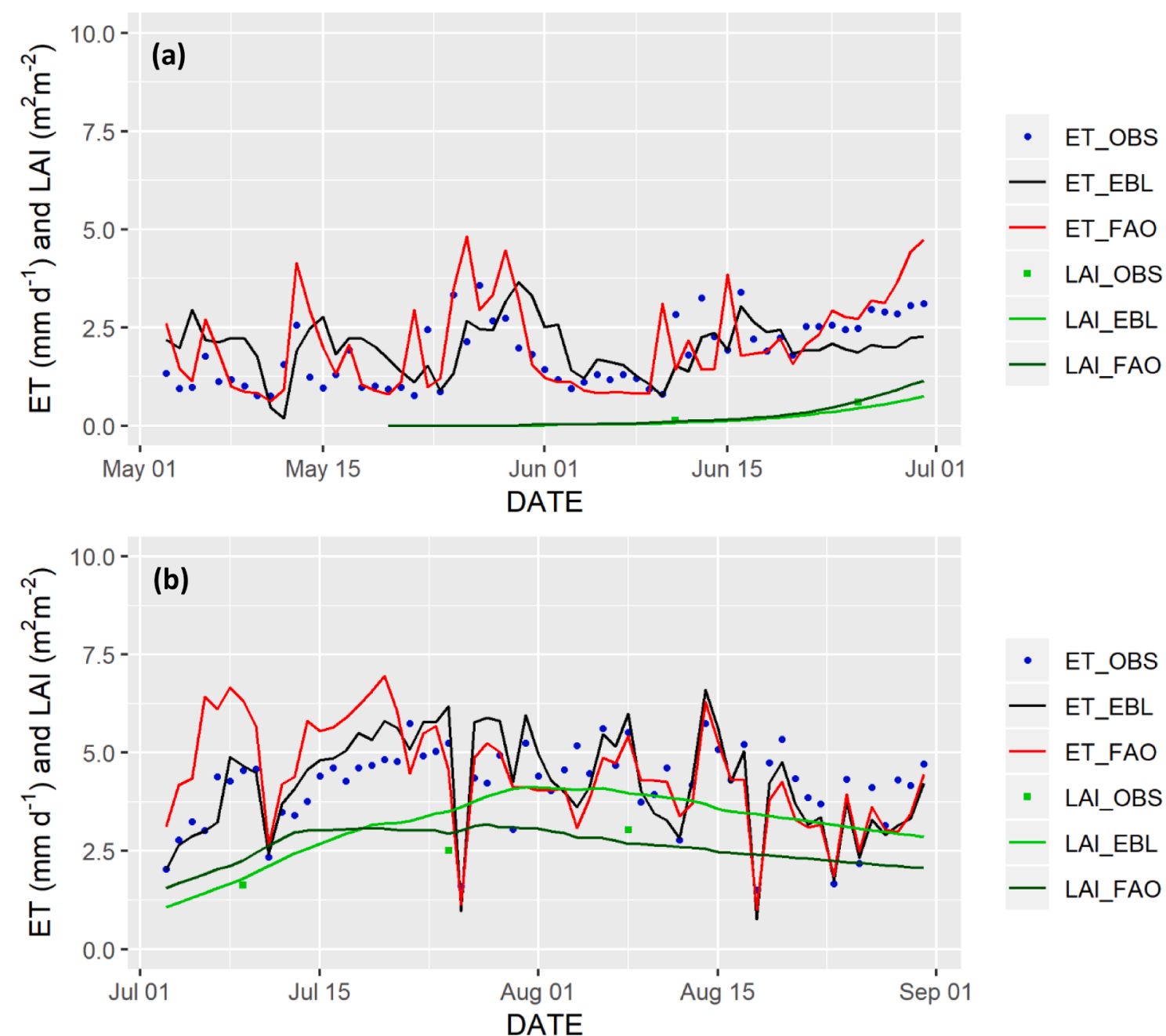

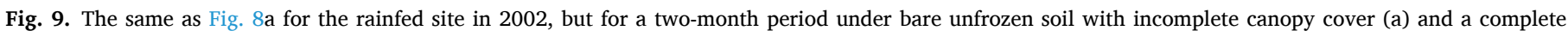
soybean canopy (b). . 
equations in the EBL model to compute the $\mathrm{CO}_{2}$ concentration inside the leaves:

$C_{\mathrm{s}}=C_{\mathrm{a}}-\frac{A_{\mathrm{n}}}{g_{\mathrm{b}}}$

$C_{\mathrm{i}}=C_{\mathrm{s}}-\frac{1.6 \times A_{\mathrm{n}}}{g_{\mathrm{s}}}$

where, $C_{\mathrm{a}}, C_{\mathrm{s}}$, and $C_{\mathrm{i}}$ are the ambient leaf surface and intercellular $\mathrm{CO}_{2}$ concentrations ( $\mu \mathrm{mol} \mathrm{mol}^{-1}$ ), respectively. $g_{\mathrm{b}}$ is the boundary layer conductance for $\mathrm{CO}_{2}$, which was computed as in Pollard et al. (1995).

\subsection{Experimental field data}

Field experiments were located at the University of Nebraska Agricultural Research and Development Center near Mead, Nebraska, USA (http://csp.unl.edu/public/), where the eddy covariance technique was used to measure fluxes of water vapor, sensible heat, and $\mathrm{CO}_{2}$ of soybean and maize in alternate years. Additional details can be found in Suyker and Verma (2008, 2009) and Suyker et al. (2004), (2005). Briefly, fluxes of latent heat, sensible heat, and momentum were made using the following sensors at each site: an omnidirectional 3D sonic anemometer (Model R3: Gill Instruments Ltd., Lymington, UK) and an open-path infrared $\mathrm{CO}_{2} / \mathrm{H}_{2} \mathrm{O}$ gas analyzing system (Model LI7500: Li-Cor Inc., Lincoln, NE).

Fetch at site of the instruments near the centers of the soybean fields was about $400 \mathrm{~m}$ in all directions. The eddy covariance sensors were mounted $3.0 \mathrm{~m}$ above the ground. Fluxes were corrected for inadequate sensor frequency, and they were also adjusted for the variation in air density due to the transfer of water vapor and sensible heat. Air temperature and humidity (Humitter50Y, Vaisala, Helsinki, FIN), net radiation at $5.5 \mathrm{~m}$ (CNR1, Kipp and Zonen Ltd., Delft, NLD), and soil heat flux (0.06 m depth; Radiation \& Energy Balance Systems Inc.,Seattle, WA) were also measured. Missing data due to sensor malfunction, power outages, unfavorable weather, etc. (approximately 15-20\% per year), were estimated using an approach that combined measurement, interpolation, and empirical data synthesis. When hourly values were missing (day or night), the latent heat values were estimated as a function of available energy. Linear regressions between latent heat and available energy were determined (separately for dry and wet conditions) for sliding 3-day intervals, and used to fill in missing flux values.

To check closure of the energy balance, the sum of latent and sensible heat fluxes $(\lambda E+H)$ measured by eddy covariance were plotted against the sum of $R_{\mathrm{n}}$ (net radiation) + three storage terms, measured by other methods. Linear regressions were calculated between the hourly values of $H+\lambda E$ and $R_{\mathrm{n}}+G$ at the study sites (excluding winter months and periods with rain and irrigation). Here $G=G_{\mathrm{s}}$ (soil heat storage) $+G_{\mathrm{c}}$ (canopy heat storage) $+G_{\mathrm{m}}$ (heat stored in the mulch) $+G_{\mathrm{p}}$ (energy used in photosynthesis). The regression slopes averaged $0.89 \pm 0.08$, implying a fairly good closure of the energy balance.

We used values of daily ET flux, called Observed-ET in the results section for 2002, 2004, 2006, and 2008 from the US-Ne2 (41 $09^{\prime} 53.5^{\prime \prime}$ $\mathrm{N}, 96{ }^{\circ} 28^{\prime} 12.3^{\prime \prime} \mathrm{W}, 362 \mathrm{~m}$; http://ameriflux.lbl.gov/sites/siteinfo/ US-Ne2) irrigated maize-soybean rotation field (Zea mays, L.; Glycine max [L.] Merr.) and from the US-Ne3 (41 $10^{\prime} 46.8^{\prime \prime} \mathrm{N}, 96{ }^{\circ} 26^{\prime} 22.7^{\prime \prime} \mathrm{W}$, $363 \mathrm{~m}$; http://ameriflux.lbl.gov/sites/siteinfo/US-Ne3) rainfed maizesoybean rotation field. Conservation tillage practices were used, so plant residues were not ploughed into the soil, and the soil surface was generally partially covered with residue. Both sites are part of the Ameriflux (https://ameriflux.lbl.gov/sites) U.S. surface gas flux observation system, and the two sites are within $1.6 \mathrm{~km}$ of each other. The cultivars Asgrow 2703, Pioneer 93B09, Pioneer 93M11, and Pioneer 93M11 were used in 2002, 2004, 2006, and 2008, respectively.

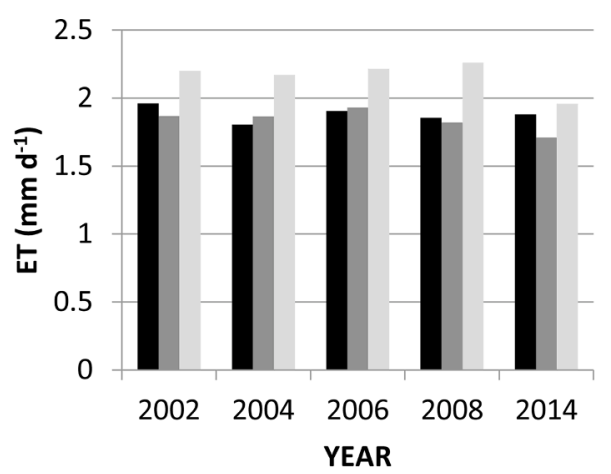

- OBS $\square B L \square$ FAO

(a)

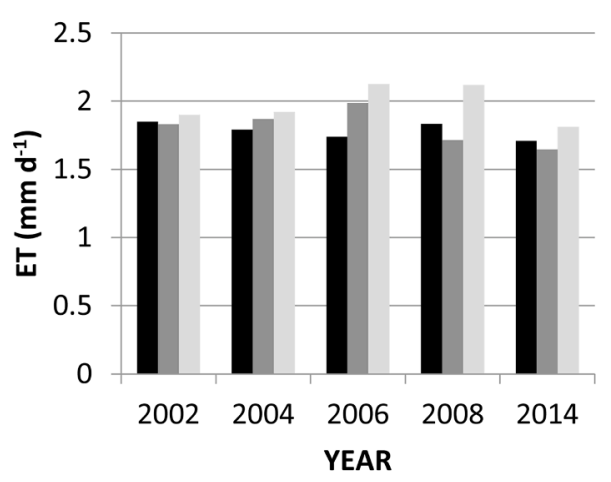

- OBS EBL $\square$ FAO

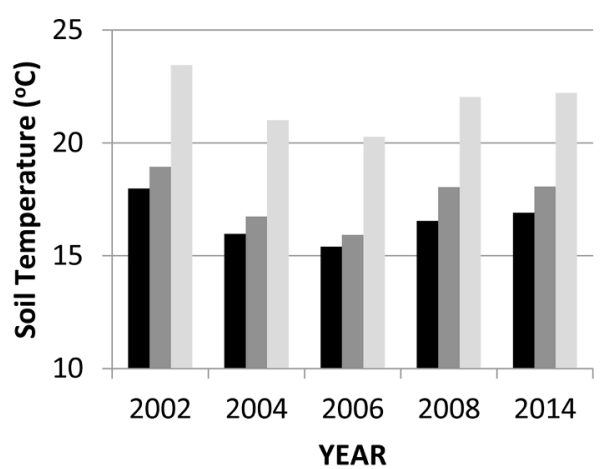

-OBS $\square \mathrm{EBL} \square \mathrm{FAO}$

(b)

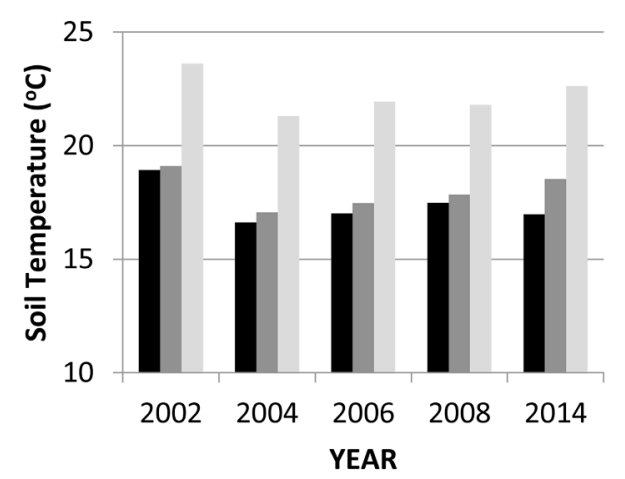

-OBS EBL $\square$ FAO
Fig. 10. Average daily observed (black bars) evapotranspiration $\left(\mathrm{mm} \mathrm{D}^{-1}\right)$ and those simulated by the CG-EBL model (dark gray bars) versus the CG-FAO56 (light gray bars), for irrigated (a) and rainfed (c) treatments for the 2002, 2004, 2006, 2008 and 2014 growing seasons. Also shown are observed soil temperatures $\left({ }^{\circ} \mathrm{C}\right)$ at 5 -cm depth for irrigated (b) and rainfed (d) treatments, for the CG-FAO56, that uses the STEMP subroutine for soil temperatures (b and d; light gray bars), and CG-EBL model (b and d; dark gray bars). . 


\subsection{Model calibration}

We used the observed soybean growth data (LAI, leaf, stem, pod, and total biomass) from the irrigated site (NE-IRR) to calibrate the genetic coefficients of the cultivars (predominantly phenology, but a few other parameters) and the observed growth from the rainfed site (NE-RNF) to independently evaluate the calibrations. For the EBL model, the soil thermal conductivity from soil surface to first soil layer was adjusted, which affects the soil heat flux.

The daily evapotranspiration from EBL model and DSSAT's FAO-56 method (Allen et al., 1998) were evaluated using four statistical parameters: arithmetic mean (MEAN), Mean Absolute Error (MAE), root

\section{NE-RFD (2002)}

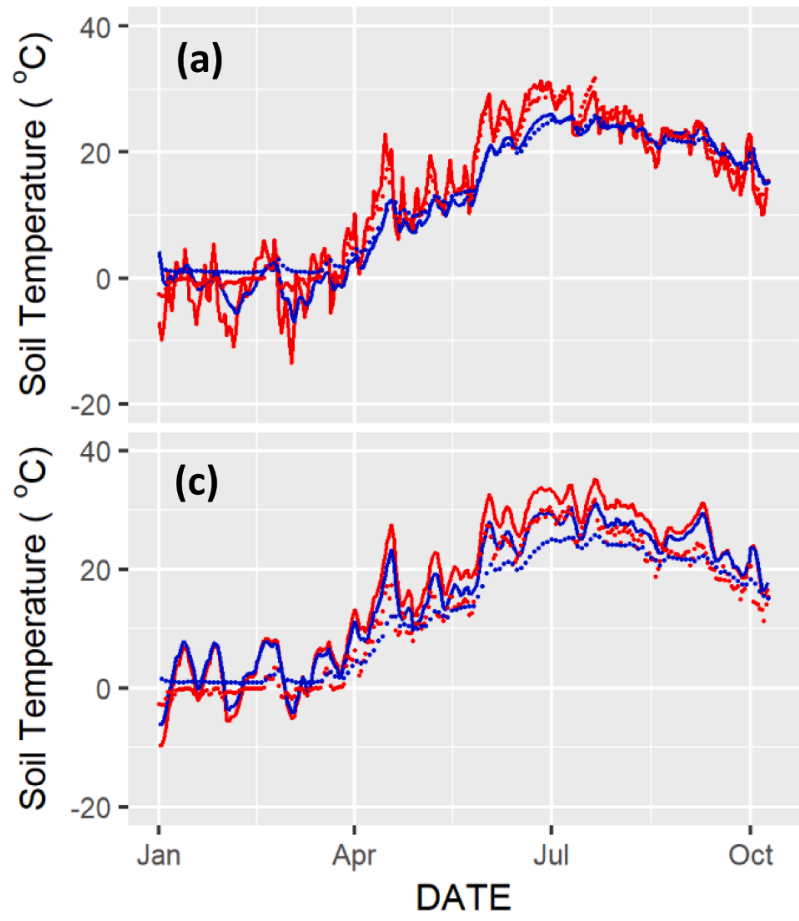

NE-RFD (2006)

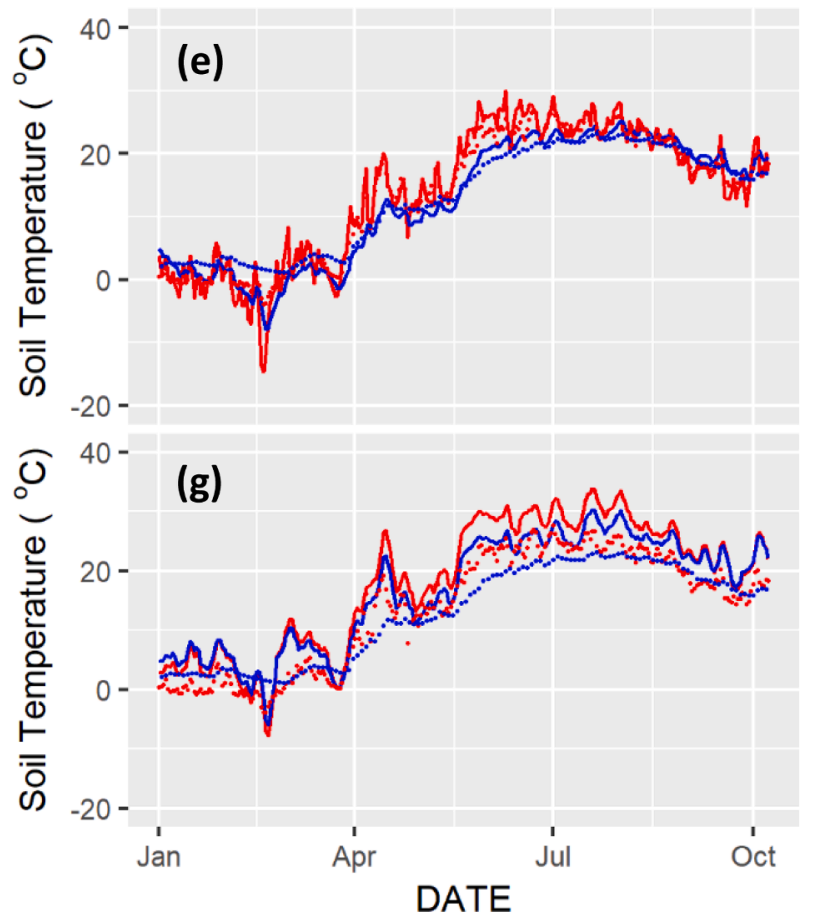

\section{NE-RFD (2004)}

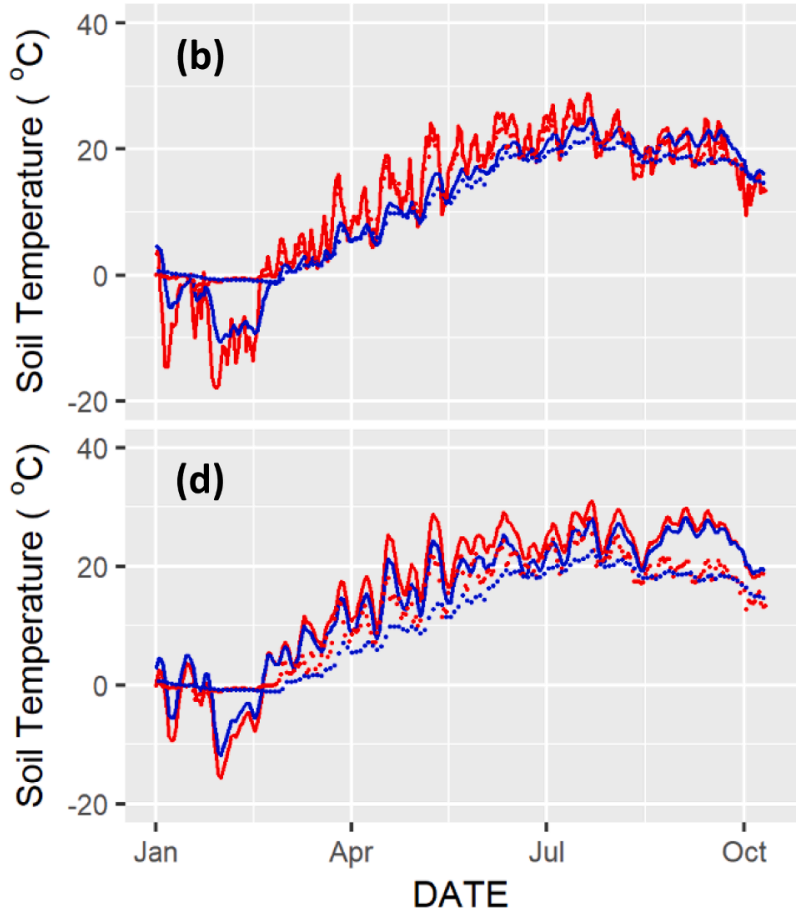

NE-RFD (2008)
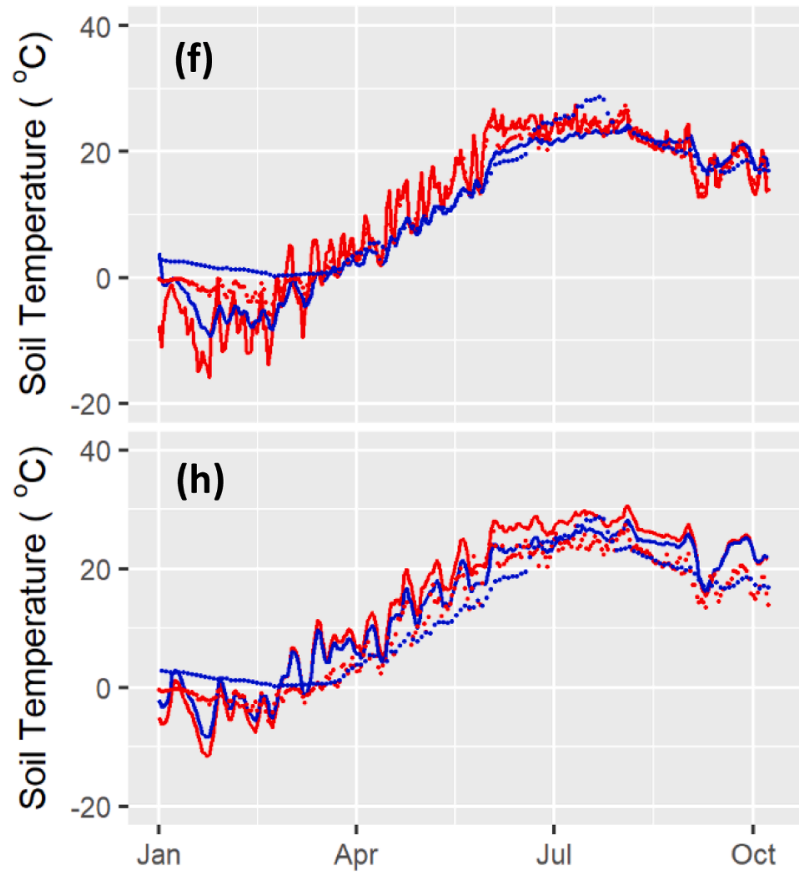

DATE

Fig. 11. Observed (symbols) and simulated soil temperatures by the CROPGRO model, with the EBL model (CG-EBL, a, b, e, f) and FAO-56 evapotranspiration and STEMP methods (CG-FAO56, c, d, g, h), at $5 \mathrm{~cm}$ (red) and $50 \mathrm{~cm}$ (blue) depths, for 2002 (a, b), 2004 (c, d), 2006 (e, f), and 2008 (g, h). (For interpretation of the references to colour in this figure legend, the reader is referred to the web version of this article.) 
mean square Error (RMSE), and the index of agreement (D-statistic, Willmott, 1982). MAE, RMSE, and the D-statistic were computed using Eqs. (18), 19, and 20, respectively:

MAE $=n^{-1} \sum_{i=1}^{n}\left|P_{i}-O_{i}\right|$

$\operatorname{RMSE}=\left[n^{-1} \sum_{i=1}^{n}\left(P_{i}-O_{i}\right)^{2}\right]^{0.5}$

$D=1-\left[\frac{\sum_{i=1}^{n}\left(P_{i}-O_{i}\right)^{2}}{\sum_{i=1}^{n}\left(\left|P_{i}-O_{m}\right|+\left|O_{i}-O_{m}\right|\right)^{2}}\right], 0 \leq D \leq 1$

where, $\mathrm{P}_{\mathrm{i}}$ and $\mathrm{O}_{\mathrm{i}}$ are the predicted and observed values for the $i$ th data pair, and $\mathrm{O}_{\mathrm{m}}$ is the mean of the observed variable, and $\mathrm{n}$ is the number of observed values.

\section{Results}

\subsection{Impacts of EBL modifications}

Stomatal conductance was made more sensitive to vapor pressure deficit $\left(D_{s}\right)$ with the adaptation of the Ball-Berry-Leuning function eq. (14) and (15). The reduction in $g_{s}$ with rising $D_{s}$ has a cost on leaf photosynthesis that is accounted for by reducing the internal $\mathrm{CO}_{2}$ concentration $\left(C_{\mathrm{i}}\right)$. As seen in Fig. 2 , as $D_{\mathrm{s}}$ increases above a threshold, the $g_{\mathrm{s}}$ declines, causing a reduction in $C_{\mathrm{i}}$ eq. (16) and (17) and an associated reduction in leaf photosynthesis. Note that now the ratio of intercellular to ambient $\mathrm{CO}_{2}\left(C_{\mathrm{i}} / C_{\mathrm{a}}\right)$ is no longer fixed (as in original formulation), and varies as a function of $C_{\mathrm{a}}$ and net $\mathrm{CO}_{2}$ leaf assimilation rate $\left(A_{\mathrm{n}}\right)$, as well as stomatal $\left(g_{\mathrm{s}}\right)$ and leaf boundary layer $\left(g_{\mathrm{b}}\right.$, dependent on leaf size and wind speed) conductances.

Fig. 3 illustrates the impacts of the new implementations in the simulations of EBL model evapotranspiration (ET). The figure shows the observed ET from flux tower (eddy covariance, see Section 2.5) and
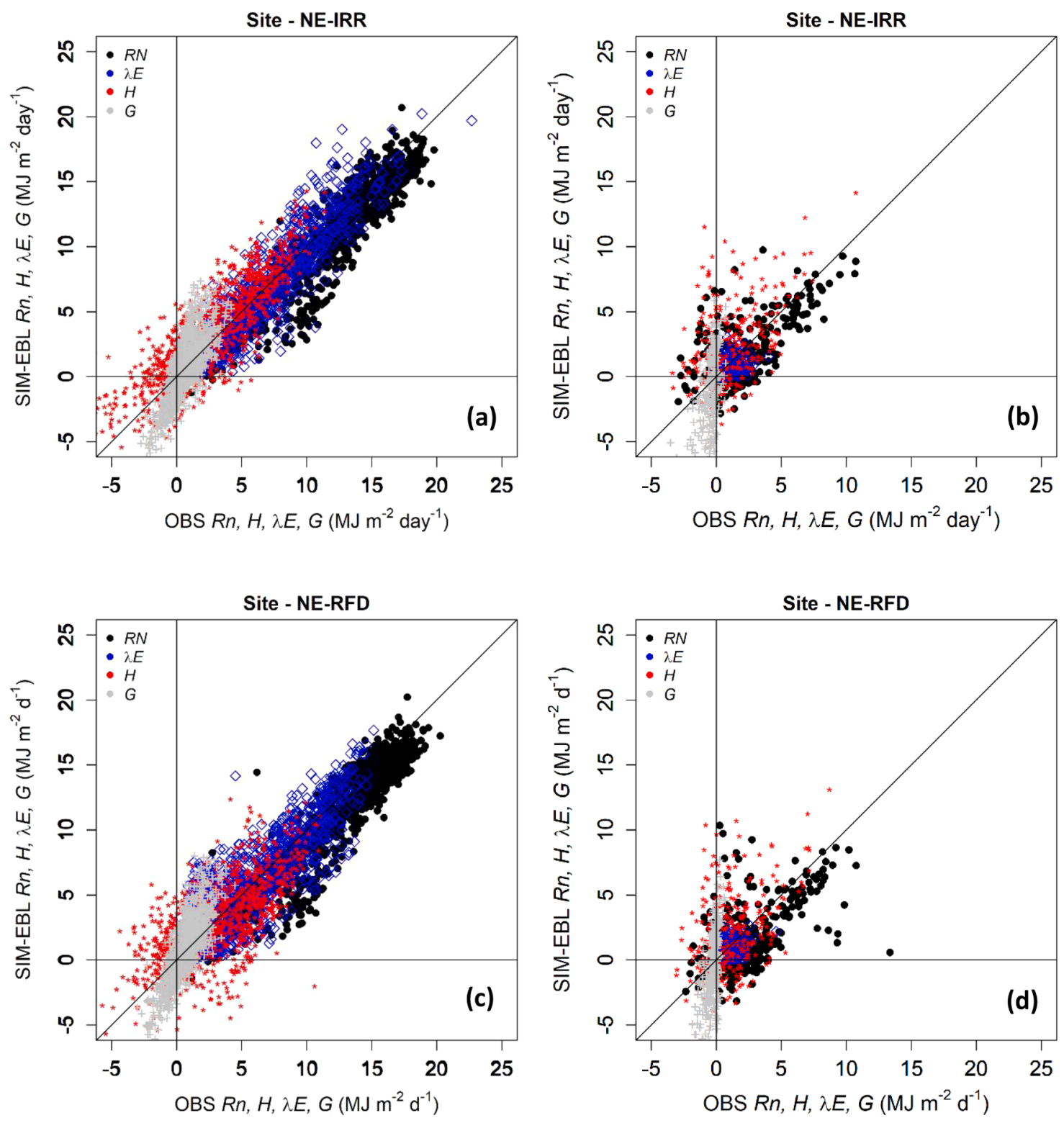

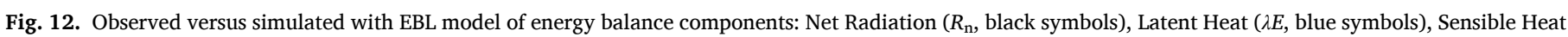

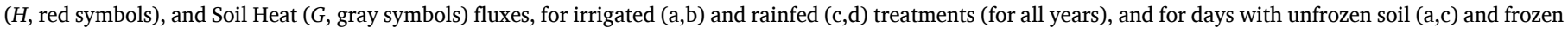
soil $(b, d)$. (for interpretation of the references to colour in this figure legend, the reader is referred to the web version of this article.) 
simulated ET with the EBL model (with and without the new implementations for $r_{\mathrm{s}, \mathrm{ss}}$ and $g_{\mathrm{s}}$, Eqs. (7)-15) and FAO-56 parametrization for a two-month period during the transition from bare to incomplete canopy cover Fig. 3a) and another two-month period with complete canopy cover (Fig. 3b). It is clear that without the restriction of the total amount of water readily available for E, the EBL model (eq. (9)-(12) overestimated E Fig 3a, EBL_ORG green line). With the new hourly water balance implementation and its impacts on $r_{\mathrm{s}, \mathrm{ss}}$ (eq. (9)-(12), we significantly improved the $\mathrm{E}$ predictions. Additionally, the new $g_{\mathrm{s}}$ equations eq. (14)-(15) lessened the high ET peaks for those days when the atmospheric evaporative demand was high (Fig. 3b).

\subsection{Evaluation of CROPGRO growth simulations with EBL and FAO-56 methods}

CROPGRO simulations of crop components with both ET methods, DSSAT's FAO-56 (CG-FAO56) or the EBL (CG-EBL), produced similar results for the calibration comparisons for irrigated treatments (Fig. 4a, c). The RMSEs for total above-ground and pod dry biomass ( $\left.\mathrm{kg} \mathrm{ha}^{-1}\right)$ were 844 and 275, respectively, with the CG-EBL, and 796 and 287, respectively, with the CG-FAO56. For the evaluation of rainfed treatments (Fig. 4b,d), CG-FAO56 tended to underestimate the biomass, mainly for stem and pod biomass (see Fig. 5), As we will see later, greater ET and more water-limitation with the use of FAO-56 parametrization was the cause for under-estimating biomass in some rainfed seasons. The RMSE for rainfed above-ground and pod dry biomass (kg ha $^{-1}$ ) with the CG-EBL was 858 and 199, respectively, and 1006 and 479, respectively, with the CG-FAO56 parametrization.

Fig. 5 presents the time-series observed and simulated results for aboveground (tops), stem, leaf and pod dry biomass $\left(\mathrm{kg} \mathrm{ha}^{-1}\right)$, for the rainfed site, NE-RNF. In general, CROPGRO with both ET models produced good results. However, for the years with more severe water stress, 2002 and 2004, the CG-EBL performed better than the CG-FAO56. For those drier years CG-FAO56 under-predicted late season total biomass, stem and pod biomass.

For frozen soil days at the irrigated site (Table 1, Figs 6a,c) neither the CG-EBL (Fig. 6a,c) nor CG-FAO56 (Fig. 6b,d) were able to simulate ET (mostly E) well, but absolute errors were small under these low ET times. The ET simulations were much better for the unfrozen (SUF) period (Fig. 6, Table 1). For the complete canopy period (CC) the CGEBL predicted ET well, while for the incomplete canopy (IC), it tended to overpredict/underpredict for those days with low/high ET (Fig. 6a, c). The CG-FAO56 tended to over-predict ET for the IC and CC periods for the irrigated site (Fig. 6b), and slightly under predict ET for complete canopy (CC) for the rainfed site (Fig. 6d), but that was caused by earlier water depletion (and less soil water remaining). Not shown here is the fact that the soil evaporation was a higher fraction of the daily ET for the CG-FAO56 case than the CG-EBL case, which was driven by the Suleiman-Ritchie (Suleiman and Ritchie, 2003, 2004) soil evaporation method. That method depleted soil water during the SUF and IC periods leaving less soil water for transpiration and photosynthesis, consistent with the report from Kimball et al. (2019) that it contributes to overprediction of ET. If the FAO-56 case had used the older Stage 1 soil evaporation (Ritchie, 1972), its performance likely would have been better (Kimball et al., 2019). In contrast, the EBL method derives its own soil evaporation rate.

Both the CG-EBL and CG-FAO56 models simulated coherent seasonal and daily fluctuations in the daily temporal ET for 2002 (Figs. 7 and 8), the year with the most severe water stress (Fig. 8). Soil water content was simulated very well by both models (shown only for EBL) for both sites. Up to April, air temperature was around $0^{\circ} \mathrm{C}$, and ET was relatively small, usually lower than $1 \mathrm{~mm} \mathrm{D}^{-1}$. During this period, even though daily fluctuations had low correlation, the models were able to simulate monthly fluctuations and values of similar magnitude. From April to the partial development of the canopy, SUF and IC periods, models followed the daily fluctuations better. During the complete canopy period (CC), both ET methods simulated high daily fluctuations, and for many days, observations showed lower daily peak fluctuations, while the models simulated both higher and lower values (Figs. 5 and 6). Additionally, CG-FAO56 simulated more frequent and higher daily peaks.

For days with unfrozen soil (Fig. 9a) both models simulated the daily ET variability, and the transition from unfrozen soil to incomplete canopy well. One can see that the CG-FAO56 model tended to simulate higher peak daily fluctuations than were observed especially during bare soil and incomplete canopy (Fig. 9a) and during low LAI period of complete canopy (Fig. 9b), a phenomenon that we attribute to use of the Sulieman-Ritchie soil evaporation method.

Thus, in general, crop growth, evapotranspiration, and soil moisture
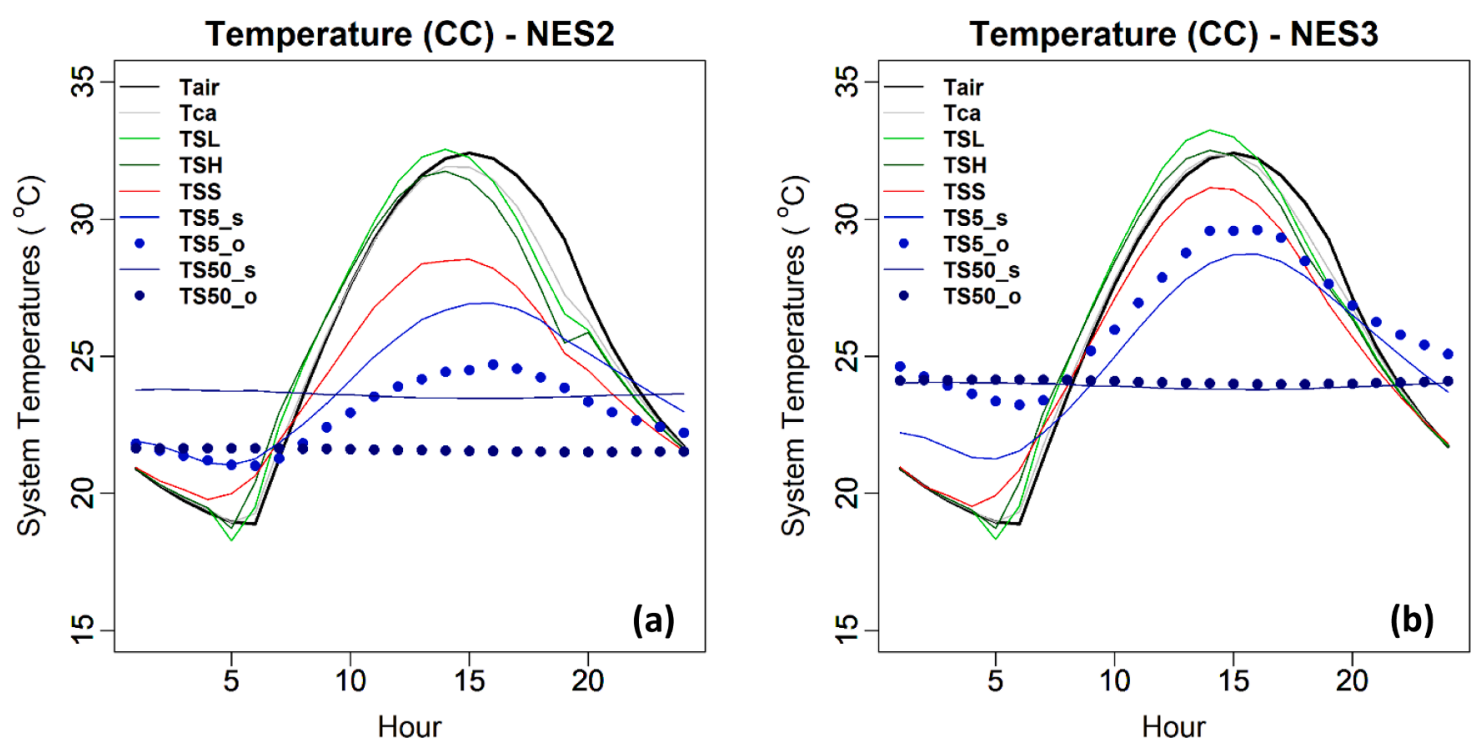

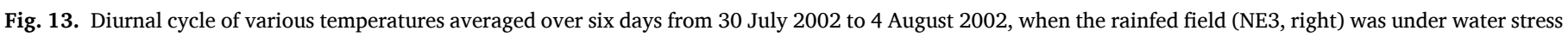

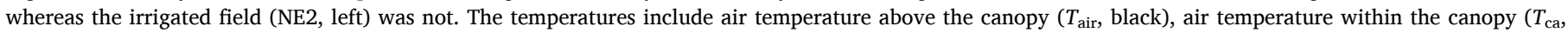

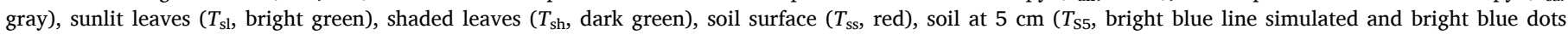

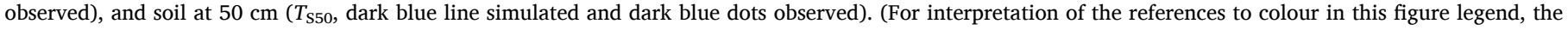
reader is referred to the web version of this article.) 
Table 2

Summary of the methods that differ between the original CROPGRO model with FAO56 option (CG-Orig) and the CROPGRO energy balance option (CG-EBL), including modifications of the energy balance code.

\begin{tabular}{|c|c|c|}
\hline Item & CG-Orig & CG-EBL \\
\hline Authors & $\begin{array}{l}\text { Boote et al. (1998); } \\
\text { Hoogenboom et al. (2019) }\end{array}$ & $\begin{array}{l}\text { Jagtap and Jones (1989); } \\
\text { Pickering et al. (1995); and } \\
\text { this paper }\end{array}$ \\
\hline Time step & $\begin{array}{l}\text { Daily except for internal } \\
\text { hourly for leaf-canopy } \\
\text { photosynthesis }\end{array}$ & $\begin{array}{l}\text { ET hourly, soil temperature } \\
\text { variable }\end{array}$ \\
\hline $\begin{array}{l}\text { Temperature } \\
\text { Linkage to } \\
\text { photosynthesis }\end{array}$ & $\begin{array}{l}\text { Air temperature } \\
\text { (Parton and Logan, 1981) }\end{array}$ & Canopy air temperature \\
\hline Potential ET & $\begin{array}{l}\text { FAO-56 Penman Monteith } \\
\text { with 12-cm grass reference } \\
\text { crop }\end{array}$ & Not required \\
\hline Actual ET & $\begin{array}{l}\text { Crop energy-extinction } \\
\text { coefficient for partitioning E } \\
\text { and T, EORATIO for LAI } \\
\text { effect on ETo (Sau et al., } \\
\text { 2004); and soil E by ( } \\
\text { Suleiman and Ritchie, 2003, } \\
2004 \text { ) }\end{array}$ & $\begin{array}{l}\text { Hedgerow light adsorption } \\
\text { model and energy balance } \\
\text { model }\end{array}$ \\
\hline $\begin{array}{l}\text { Aerodynamic } \\
\text { Resistance }\left(r_{\mathrm{a}}\right)\end{array}$ & $\begin{array}{l}\text { Wind speed effect on } r_{\mathrm{a}} \\
\text { (Allen et al., 1998) }\end{array}$ & $\begin{array}{l}r_{\mathrm{a}} \text { equation (Brutsaert, } \\
\text { 1982) and stability } \\
\text { correction (Chowdhury } \\
\text { et al. 1986). Now, } r_{\mathrm{a}} \\
\text { considers stability } \\
\text { correction to account for } \\
\text { thermal gradients under } \\
\text { calm conditions (Kimball } \\
\text { et al., 2015) }\end{array}$ \\
\hline $\begin{array}{l}\text { Boundary layer } \\
\text { resistances }\end{array}$ & (Allen et al., 1998) & $\begin{array}{l}r_{\mathrm{b}} \text { (Chowdhury and Monteit } \\
\mathrm{h} \text { (1988). Now, } r_{\mathrm{b}} \text { for sl and } \\
\text { sh leaf classes follows } \\
\text { Pollard et al. (1995), } r_{\mathrm{s}, \mathrm{sl}} \\
\text { and } r_{\mathrm{s}, \mathrm{sh}} \text { follow the BBL } \\
\text { model Leuning, 1995) for } \\
\text { stomatal conductance (eq. } \\
\text { (14)-(15) }\end{array}$ \\
\hline $\begin{array}{l}\text { Intercellular } \mathrm{CO}_{2} \\
\text { concentration } \\
\left(C_{\mathrm{i}}\right)\end{array}$ & $\begin{array}{l}C_{\mathrm{i}} \text { equal to } 0.7 \text { of the ambient } \\
\text { concentration }\left(C_{\mathrm{a}}\right)\end{array}$ & $\begin{array}{l}C_{\mathrm{i}} \text { computed eq. (16)-(17) } \\
\text { as function of } C_{\mathrm{a}} \text {, net } \mathrm{CO}_{2} \\
\text { leaf assimilation rate, and } \\
\text { stomatal and leaf boundary } \\
\text { layer conductances }\end{array}$ \\
\hline Soil temperature & $\begin{array}{l}\text { Annual cosine curve with } \\
\text { attenuation and time lag for } \\
\text { layers }\end{array}$ & $\begin{array}{l}\text { From surface energy } \\
\text { balance and integration of } \\
\text { eq. ( } 7 \text { ), considering a } \\
\text { variable time step to ensure } \\
\text { numerical stability }\end{array}$ \\
\hline Soil evaporation & $\begin{array}{l}\text { Daily water balance ( } \\
\text { Suleiman and Ritchie (2003, } \\
\text { 2004) }\end{array}$ & $\begin{array}{l}\text { Internal hourly water } \\
\text { balance }\end{array}$ \\
\hline
\end{tabular}

were consistently simulated well by CROPGRO with the FAO-56 (CGFAO56) and the EBL (CG-EBL) methods (Figs. 5-9, Table 1). CG-EBL improved the ET predictions slightly (Fig. 10a,c, Table 1), under irrigated and rainfed conditions, with closer simulated averages in nine of the ten growth cycles evaluated.

A significant improvement was achieved for the simulation of soil temperature at the various depths evaluated. Fig. 10b,d shows that CGEBL simulates values closer to observed soil temperatures for all years and treatments when compared to the CG-FAO56, that uses the DSSAT STEMP subroutine for simulating soil temperature.

Both models captured seasonal soil temperature patterns well at 5 and $50 \mathrm{~cm}$ depths (Fig. 11). During the first months of the years, observations showed more stable soil temperatures, around $0{ }^{\circ} \mathrm{C}$, while the models simulated daily and weekly oscillations. This can be explained by the fact that none of the DSSAT models consider snow cover for insulation effects, so the insulating effect of snow cover on soil temperature was not simulated. Even though the model results can be simulated over snowy periods, users should keep in mind that the present formulation of DSSAT models is incomplete for this condition. Most of the time, it is clear the CG-EBL model simulated soil temperatures better than the CG-FAO56. Observed average soil temperature at 5 $\mathrm{cm}$ for all years was $12.8{ }^{\circ} \mathrm{C}$, and simulated values by CG-EBL and CGFAO56 were 13.6 and $16.6^{\circ} \mathrm{C}$, respectively.

Both models tended to simulate higher temperatures from April until the end of crop season. Daily fluctuations were well simulated for all layers, the Nash-Sutcliffe efficiency (NSE) for 5/50-cm soil depth was $0.87 / 0.84$ and $0.71 / 0.66$ for CG-EBL and CG-FAO56, respectively. It is important to note that the soil temperature simulation method for the DSSAT-STEMP is empirical and relatively simple. It varies with day of year, annual amplitude of monthly mean temperature (coldest to warmest months), solar radiation, and daily maximum air temperature. The DSSAT default soil temperature method, STEMP, has previously been shown to over-predict soil temperature, especially in summer (Salmeron et al., 2014).

\subsection{Evaluation of EBL model components}

Fig. 12 shows daily energy balance components for all years. For those days with unfrozen soil (Fig. 12a,c), net radiation was simulated well by the EBL model for almost all days for both the irrigated and rainfed treatments. Latent heat flux was also close to observed values for most days, but it had some overestimation, mainly for the rainfed site. A similar pattern applies for sensible heat flux. Soil heat fluxes show less consistent results and tended to under- or over-predict fluxes for those days with lower or higher soil heat fluxes, respectively. As explained above, DSSAT does not consider snow, and even though the models can simulate fluxes for days with frozen soil, results likely are not accurate (Fig. 12b,d).

Although no observed canopy temperatures were available for comparison, the CG-EBL simulated temperatures appear to respond generally as expected (Fig. 13). In both the irrigated and rainfed fields the simulated sunlit and shaded leaf temperatures, as well as the canopy air temperature, lead the rise in air temperature above the crops during the morning hours. Then, in the afternoon they are cooler than air temperature and similarly lead the decrease in air temperature. The leaf temperatures in the irrigated field in the afternoon are several degrees below air temperature and are lower than those in the rainfed field. Also, the soil surface and $5-\mathrm{cm}$ soil temperatures were much higher under rainfed compared to irrigated conditions. During this period, the observed daily average ET from the irrigated field was $6.76 \mathrm{~mm}$, whereas it was only half as much $(3.33 \mathrm{~mm})$ in the rainfed field. This reduced ET rate strongly suggests that the rainfed field was under water stress leading to the higher leaf and soil temperatures compared to the irrigated, non-water-stress condition.

The $T_{\mathrm{ca}}, T_{\mathrm{sl}}$, and $T_{\mathrm{sh}}$ temperatures are close to one another for most of the time for both irrigated and rainfed conditions. For the simulations of temperature-dependent growth processes, CROPGRO uses a variable called TGRO. Normally, TGRO is set equal to Class A weather station air temperature. However, for our CG-EBL simulations (e.g., Fig. 5), we set TGRO equal to $T_{\text {ca. }}$. We had speculated that perhaps an area-weighted average of $T_{\mathrm{sl}}$ and $T_{\mathrm{sh}}$ should be used, but in this case $T_{\mathrm{ca}}$ is close to both of them, and it appeared to work well (Figs. 4, 5).

\section{Discussion}

Resurrecting the dormant energy balance code in the CROPGRO model required much effort. However, once the linkages were restored and the model was running and stable, we realized that, compared to the Nebraska observations, it performed well as originally coded under some conditions, but performed poorly under some other conditions. This led us to implement several changes in the code, as summarized in Table 2.

After those changes, crop growth and evapotranspiration of soybean over four seasons under irrigated and rainfed conditions at a Nebraska 
eddy flux site were consistently simulated well by CROPGRO with both the FAO-56 method [Penman-Monteith (Allen et al., 1998)] evapotranspiration method (CG-FAO56) and the Energy Balance (EBL) model (CG-EBL, Jagtap and Jones, 1989; Pickering et al., 1995). This first evaluation of the improved CG-EBL model was successful, showing simulated ET values similar to those of the CG-FAO56 option and somewhat closer to observed ET, especially during the unfrozen soil and the incomplete canopy periods. The CG-EBL option improved the seasonal average ET predictions slightly over CG-FAO56 for 4 of the 5 years evaluated for irrigated and rainfed conditions. The CG-EBL soil temperatures at the various depths were much better simulated than the CG-FAO56 which uses the DSSAT's default soil temperature method (STEMP).

Although the original EBL option was closer to observed ET during the unfrozen soil and incomplete canopy periods, the version with the original formulation for stomatal conductance (as well as the FAO-56 option) tended to over-estimate ET on high ET days during the full canopy period (Fig. 3). This overestimation led us to suspect there was a need to incorporate effects of large $D_{\mathrm{s}}$ to reduce stomatal conductance under these relative hot and dry conditions. Therefore, we incorporated a modification of the Ball-Berry-Leuning (BBL) equation (Leuning, 1995; Miner et al., 2017; Gilbert et al., 2011) into the EBL model, which improved the accuracy of the simulated ET under high ET conditions and full canopy cover (Fig. 6a,c). As seen in Fig. 2, as $D_{s}$ increases above a threshold the modeled $\mathrm{g}_{s}$ declines, causing a reduction in ET. The modeled reduction in $\mathrm{g}_{\mathrm{s}}$ with rising $D_{\mathrm{s}}$ has a cost on leaf photosynthesis that is implemented by reducing the internal $\mathrm{CO}_{2}$ concentration $\left(C_{\mathrm{i}} / C_{\mathrm{a}}\right)$. Note that the $C_{\mathrm{i}} / C_{\mathrm{a}}$ during leaf photosynthesis is no longer fixed (as in the original formulation, Fig. 2a,b).

By solving the energy balance explicitly, the EBL model has the advantage that the physical processes are evaluated individually, in contrast to the FAO-56 and the other ET methods available in DSSAT. Additionally, the canopy energy balance predicts both ET and the canopy temperature, thus allowing the leaf photosynthesis model and other growth processes to depend on actual foliage temperature rather than air temperature. For example, in arid regions with irrigation, canopy temperatures can be several degrees below air temperature (e.g., Jackson et al., 1981, Allen et al., 2003), and as illustrated in Fig. 13.

Another motivation for the development of a leaf-based model for canopy gas exchange is the desire to accurately predict response of plant canopies to the environment. Atmospheric carbon dioxide concentration $\left[\mathrm{CO}_{2}\right]$ has increased markedly in the last 50 years and global air temperatures are also increasing (IPCC, 2013). The complexity of plant response to $\mathrm{CO}_{2}$, air temperature, and water stress lend themselves to a detailed modeling approach (Reynolds and Acock, 1985). Known biochemical responses to environmental responses can be modeled at leaf level then scaled to the canopy and the growing season. The inclusion of a modified Ball-Berry-Leuning (BBL) equation includes explicit reduction in $g_{\mathrm{s}}$ as affected by $C_{\mathrm{s}}$, which has a mechanistic approach for $\mathrm{CO}_{2}$-driven reductions in transpiration.

Process-based models also have the potential to assist plant breeders in the search for cultivars with higher yield potential and better adaptation to different production environments (Yin et al., 2003). Explicitly solving the interaction of the plant with the environment, the EBL model enables evaluation of the interactions between the crop and the environment. For example, crop management scenarios could evaluate how different planting densities and leaf architecture (e.g., cultivars with upright or decumbent leaves) could affect canopy temperature, soil temperature, and soil evaporation.

\section{Conclusions}

The EBL energy balance model (Jagtap and Jones, 1989; Pickering et al., 1995) within the ETPHOT routine of the widely used CROPGRO model (CG-EBL) was successfully resurrected after lying dormant and untested for more than two decades. Crop growth and evapotranspiration were consistently simulated well by CG-EBL, as well as by the default DSSAT-CROPGRO model (CG-FAO56) with the FAO-56 [Penman-Monteith (Allen et al., 1998)] ET method and a simple soil temperature model (STEMP). A major improvement was achieved by the CG-EBL model over CG-FAO56 for simulation of soil temperatures for all soil layers. The EBL model represents explicitly many physical processes, in contrast to the DSSAT ET parametrizations. It thereby provides a method to explicitly simulate the impacts of crop morphology, physiology and management on the crop's environment and energy and gas exchange, which in turn affect directly the water use and irrigation requirements, phenology, photosynthesis, growth, sterility, and yield of crops. Although this new EBL is a huge step forward in terms of stability and accuracy, it will need more field testing to validate the suitability of the modeled processes with additional sources of field data. Inclusion as an option in the next version of DSSAT will allow many more users to test it under a wide range of conditions.

\section{Declaration of Competing Interest}

None

\section{Acknowledgements}

We gratefully acknowledge The Nature Conservancy of Brasil (TNC), the Gordon and Betty Moore Foundation, and the DSSAT Foundation for facilitating and funding support of this work. We also appreciate the help of Cheryl Porter, Patricia Moreno, Willingthon Pavan, Kelly Thorp, and Jeffrey White. We also appreciate access to the comprehensive dataset from Mead, Nebraska, USA, which was collected by the following scientists: Shashi B. Verma, Achim Dobermann, Kenneth G. Cassman, Daniel T. Walters, Johannes M. Knops, Timothy J. Arkebauer, George G. Burba, Brigid Amos, Haishum Yang, Daniel Ginting, Kenneth G. Hubbard, Anatoly A. Gitelson, and Elizabeth A. Walter-Shea. The dataset was collected with support from the DOE-Office of Science (BER: Grant Nos. DE-FG03-00ER62996 and DE-FG02-03ER63639), DOEEPSCoR (Grant No. DE-FG02-00ER45827), and the Cooperative State Research, Education, and Extension Service, US Department of Agriculture (Agreement No. 2001-38700-11092).

\section{References}

Allen, L.H., Pan, D., Boote, K.J., Pickering, N.B., Jones, J.W., 2003. Carbon dioxide and temperature effects on evapotranspiration and water-use efficiency of soybean. Agron J 95, 1071-1081.

Allen, R.G., Pereira, L.S., Raes, D., Smith, M., 1998. Crop Evapotranspiration: Guidelines for Computing Crop Water Requirements, FAO Irrigation and Drainage Paper 56. Food and Agriculture Organization of the United Nations, Rome, Italy.

ASHRAE (American Society of Heating, Refrigerating, and Air-Conditioning Engineers), 1972. ASHRAE Handbook of Fundamentals. ASHRAE, New York.

Boote, K.J., Jones, J.W., 1987. Equations to define canopy photosynthesis from quantum efficiency, maximum leaf rate, light extinction, leaf area index, and photon flux density. In: BIGGINS, J. (Ed.), Progress in Photosynthesis Research, 4. Martinus Niijhoff Publication, The Hague, pp. 415-418.

Boote, K.J., Loomis, R.S., 1991. The prediction of canopy assimilation. Chapter 7. In: Boote, K.J., Loomis, R.S. (Eds.), Modeling Crop Photosynthesis - From Biochemistry to Canopy. CSSA Special Publication No. 19. American Society of Agronomy, Madison, WI, pp. 109-140.

Boote, K.J., Pickering, N.B., 1994. Modeling photosynthesis of row crop canopies. HortScience 29, 1423-1434.

Boote, K.J., Jones, J.W., Hoogenboom, G., Pickering, N.B., 1998. The CROPGRO Model for Grain Legumes. In: Tsuji, G.Y, Hoogenboom, G., Thornton, P.K. (Eds.), The CROPGRO Model for Grain Legumes. Understanding Options for Agricultural Production 99-128.

Boote, K.J., Sau, F., Hoogenboom, G., Jones, J.W., 2009. Experience with Water Balance, Evapotranspiration, and Prediction of Water Stress Effects in the CROPGRO Model. In: Ahuja, L.R., Reddy, V.R., Saseendran, S.A., Yu, Q. (Eds.), Response of Crops to Limited Water: Modeling Water Stress Effects On Plant Growth Processes, Volume 1 of Advances in Agricultural Systems Modeling. ASA-CSSA-SSSA, Madison, WI.

Brutsaert, W., 1982. Evaporation into the Atmosphere Theory. History and Applications. Springer, Netherlands.

Choudhury, B.J., Monteith, J.L., 1988. A four-layer model for the heat budget of homogeneous land surfaces. Quarterly Journal of the Royal Meteorological Society $114,373-398$. 
Erbs, D.G., Klein, S.A., Duffie, I.A., 1982. Estimation of the diffuse radiation fraction for hourly, daily and monthly-average global radiation. Solar Energy 28, 293-302.

Farquhar, G.D., von Caemmerer, S., 1982. Modelling of photosynthetic response to environmental conditions. O.L. Lange, P.S. Nobel, C.B. Osmond, H. Ziegler (Eds.), "Physiological Plant Ecology II. Water Relations and Carbon Assimilation", 12B, Springer, Berlin (1982), pp. 549-587.

Gijzen, H., Goudriaan, J., 1989. A flexible and explanatory model of light distribution and photosynthesis in row crops. Agric For Meteorol 48, 1-20.

Gilbert, M.E., Holbrook, N.M., Zwieniecki, M.A., Sadok, W., Sinclair, T.R., 2011. Field confirmation of genetic variation in soybean transpiration response to vapor pressure deficit and photosynthetic compensation. Field Crops Res. 124, 85-92.

Goudriaan, J., 1988. The bare bones of leaf-angle distribution in radiation models for canopy photosynthesis and energy exchange. Agric For Meteorol 43, 155-169.

Harley, P.C., Weber, J.A., Gates, D.M., 1985. Interactive effects of light, leaf temperature, $\mathrm{CO}_{2}$ and $\mathrm{O}_{2}$ on photosynthesis in soybean. Planta 165, 249-263.

Hoogenboom, G., Porter, C.H., Shelia, V., Boote, K.J., Singh, U., White, J.W., Hunt, L.A., Ogoshi, R., Lizaso, J.I., Koo, J., Asseng, S., Singels, A., Moreno, L.P., Jones, J.W., 2017. Decision Support System For Agrotechnology Transfer (DSSAT) Version 4.7 DSSAT Foundation, Gainesville, Florida, USA. www.DSSAT.net.

Hoogenboom, G., Porter, C.H., Boote, K.J., Shelia, V., Wilkens, P.W., Singh, U., J. W., White, Asseng, S., Lizaso, J.I., Moreno, L.P., Pavan, W., Ogoshi, R., Hunt, L.A., Tsuji, G.Y., Jones, J.W., 2019. The DSSAT crop modeling ecosystem. In: Boote, K.J. (Ed.), Advances in Crop Modeling For a Sustainable Agriculture. Burleigh Dodds Science Publishing, Cambridge, United Kingdom, pp. 173-216. https://doi.org/1 0.19103/AS.2019.0061.10.

IPCC, 2013: Summary for Policymakers. In: Climate Change 2013: The Physical Science Basis. Contribution of Working Group I to the Fifth Assessment Report of the Intergovernmental Panel on Climate Change [Stocker, T.F., D. Qin, G.-K. Plattner, M. Tignor, S.K. Allen, J. Boschung et al. (eds.)]. Cambridge University Press, Cambridge, United Kingdom and New York, NY, USA.

Jackson, R.D., Idso, S.B., Reginato, R.J., Pinter Jr., P.J., 1981. Canopy temperature as a crop water stress indicator. Water Resour Res 17, 1133-1138.

Jagtap, S.S., Jones, J.W., 1989. Evapotranspiration model for developing crops. Trans. ASAE $32,1342-1350$

Jones, J.W., Hoogenboom, G., Porter, C.H., Boote, K.J., Batchelor, W.D., Hunt, L.A., Wilkens, P.W., Singh, U., Gijsman, A.J., Ritchie, J.T., 2003. DSSAT Cropping System Model. Eur. J. Agron. 18, 235-265.

Jordan, D.B., Ogren, W.L., 1984. The CO2/O2 specificity of ribulose 1,5-bisphosphate carboxylase/oxygenase. Dependence on ribulose-bisphosphate concentration, $\mathrm{pH}$ and temperature. Planta 161, 308-313.

Kimball, B., White, J., Ottman, M., Wall, G., Bernacchi, C., Morgan, J., Smith, D., 2015. Predicting canopy temperatures and infrared heater energy requirements for warming field plots. Agron. J. 107, 129-141.

Kimball, B., Boote, K., Hatfield, J.L., Ahuja, L.R., Stockle, C., Archontoulis, S., Caron, C., Basso, B., Bertuzzi, P., Constantin, J., Deryng, D., Dumont, B., Durand, J., Ewert, F., Gaiser, T., Gayler, S., Hoffmann, M.P., Jiang, Q., Kim, S., Lizaso, J., Moulin, S., Nednel, C., Parker, P., Palosuo, T., Priesack, E., Qi, Z., Srivastava, A., Tommaso, S. Tau, F., Thorp, K.R., Timlin, D.J., Twine, T.E., Webber, H., Willaume, M., Williams, K., 2019. Simulation of maize evapotranspiration: an intercomparison among 29 maize models. Agric For Meteorol 271, 264-284.

Leuning, R., 1995. A critical appraisal of a combined stomatal-photosynthesis model for C-3 plants. Plant Cell Environ. 18, 339-355.

Miner, G.L., Bauerle, W.L., Baldocchi, D.D., 2017. Estimating the sensitivity of stomatal conductance to photosynthesis: a review. Plant Cell Environ. 40, 1214-1238.

Monteith, J.L., Unsworth, M.H., 1990. Principles of environmental physics, 2nd edn. Butterworth, Oxford.

Novak, M.D., 2005. In: Hatfield, J.L., Baker, J.M. (Eds.). American Society of Agronomy, Crop Science Society of America, Soil Science Society of America, Madison, Wisconsin, USA, pp. 105-129.
Parton, W.J., Logan, J.A., 1981. A model for diurnal variation in soil and air temperature. Agric. Meteorol. 23, 205-216.

Pequeno, D.N.L., Pedreira, C.G.S., Boote, K.J., 2014. Simulating forage production of Marandu palisade grass (Brachiaria brizantha) with the CROPGRO-Perennial Forage model. Crop \& Pasture Sci. 65, 1335-1348. https://doi.org/10.1071/CP14058.

Pequeno, D.N.L., Pedreira, C.G.S., Boote, K.J, Alderman, P.D., A.F.G., Faria, 2018. Species-genotypic parameters of the CROPGRO Perennial Forage Model: implications for comparison of three tropical pasture grasses. Grass and Forage Sci. $73,440-455$.

Pickering, N.B., Jones, J.W., Boote, K.J., 1995. Adapting SOYGRO V5.42 for prediction under climate change conditions. In: Rosenzweig, C., Jones, J.W., Allen, Jr., L.H. (Eds.), Climate Change and Agriculture: Analysis of Potential International Impacts. ASA Spec. Pub. No. 59, ASA-CSSA-SSSA, Madison, WI, pp. 77-98.

Pollard, D., Thompson, S.L., 1995. Use of a land-surface-rransfer scheme (LSX) in a global climate model: the response to doubled stomatal resistance. Glob. Planet Change 10, 129-161.

Priestley, C.H.B., Taylor, R.J., 1972. On the assessment of surface heat flux and evaporation, using large scale parameters. Mon. Weather Rev. 100, 81-92.

Reynolds, J.F., Acock, B., 1985. Predicting the response of plants to increasing carbon dioxide: a critique of plants growth models. Ecol Modell 29, 107-129.

Ritchie, J.T., 1972. Model for predicting evaporation from a row crop with incomplete cover. Water Resour Res 8, 1204-1213.

Sau, F., Boote, K.J, Bostick, W.M., Jones, J.W., Minguez, M.I., 2004. Testing and improving evapotranspiration and soil water balance of the DSSAT crop models. Agron J 96, 1243-1257.

Seidel, S.J., Palosuo, T., Thorburn, P., Wallach, D., 2018. Towards improved calibration of models - Where are we now and where should we go? European J Agron. 94, 25-35.

Salmeron, M., Cavero, J., Isla, R., Porter, C.H., Jones, J.W., Boote, K.J., 2014. DSSAT nitrogen cycle simulation of cover crop-maize rotations under irrigated Mediterranean conditions. Agron J 106, 1283-1296.

Spitters, C.J.T., Toussaint, H.A.J.M., Goudriaan, J., 1986a. Separating the diffusue and direct component of global radiation and its implication for modeling canopy photosynthesis. Part 1. Components of incoming radiation. Agric For Meteorol 38, 217-229.

Spitters, C.J.T., Toussaint, H.A.J.M., Goudriaan, J., 1986b. Separating the diffuse and direct component of global radiation and its implication for modeling canopy photosynthesis. Part II. Calculation of canopy photosynthesis. Agric For Meteorol 38, 231-242.

Suleiman, A.A., Ritchie, J.T., 2003. Modeling soil water redistribution during secondstage evaporation. Soil Sci. Soc. Amer. J. 67, 377-386.

Suleiman, A.A., Ritchie, J.T., 2004. Modifications to the DSSAT vertical drainage model for more accurate soil water dynamics estimation. Soil Sci 169, 745-757.

Suyker, A.E., Verma, S.B., Burba, G.G., Arkebauer, T.J., Walters, D.T., Hubbard, K.G. 2004. Growing season carbon dioxide exchange in irrigated and rainfed maize. Agric For Meteorol 124, 1-13.

Suyker, A.E., Verma, S.B., Burba, G.G., Arkebauer, T.J., 2005. Gross primary production and ecosystem respiration of irrigated maize and irrigated soybean during a growing season. Agric For Meteorol 131, 180-190.

Suyker, A.E., Verma, S.B., 2008. Interannual water vapor and energy exchange in an irrigated maize-based agroecosystem. Agric For Meteorol 148, 417-427.

Suyker, A.E., Verma, S.B., 2009. Evapotranspiration of irrigated and rainfed maizesoybean cropping systems. Agric For Meteorol 149, 443-452.

Willmott, C.J., 1982. Some comments on the evaluation of model performance. Bull. Am. Meteorol. Soci. 63, 1309-1313.

Yin, X., Stam, P., Kropff, M.J., Schapendonk, A., 2003. Crop modeling, QTL mapping, and their complementary role in plant breeding. Agron J 95, 90-98. 